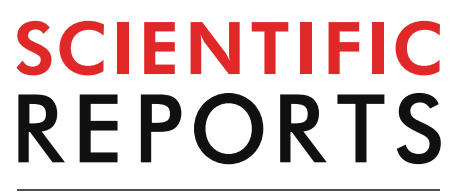

natureresearch

Check for updates

\title{
Carbon-dot-loaded $\mathrm{Co}_{x} \mathrm{Ni}_{1-x} \mathrm{Fe}_{2} \mathrm{O}_{4} ;$
} $\mathrm{x}=0.9 / \mathrm{SiO}_{2} / \mathrm{TiO}_{2}$ nanocomposite with enhanced photocatalytic and antimicrobial potential: An engineered nanocomposite
for wastewater treatment

M. Abd Elkodous $(1)^{1,2,6}$, Gharieb S. El-Sayyad (1)3,4,6, Sally M. Youssry ${ }^{1}{ }^{1}$, Hanady G. Nada (1) 3 , Mohamed Gobara $\mathbb{1}^{4}$, Mohamed A. Elsayed $\mathbb{1}^{4}$, Ahmed M. El-Khawaga $\mathbb{1}^{4}$, Go Kawamura ${ }^{1 \times}$, Wai Kian Tan $\mathbb{1}^{5}$, Ahmed I. El-Batal $\mathbb{D}^{3}$ \& Atsunori Matsuda $\mathbb{1}^{1 \bowtie}$

Water scarcity is now a serious global issue resulting from population growth, water decrease, and pollution. Traditional wastewater treatment plants are insufficient and cannot meet the basic standards of water quality at reasonable cost or processing time. In this paper we report the preparation, characterization and multiple applications of an efficient photocatalytic nanocomposite $\left(\mathrm{Co}_{x} \mathrm{Ni}_{1-x} \mathrm{Fe}_{2} \mathrm{O}_{4} ; \mathrm{x}=0.9 / \mathrm{SiO}_{2} / \mathrm{TiO}_{2} / \mathrm{C}\right.$-dots) synthesized by a layer-by-layer method. Then, the photocatalytic capabilities of the synthesized nanocomposite were extensively-studied against aqueous solutions of chloramine-T trihydrate. In addition, reaction kinetics, degradation mechanism and various parameters affecting the photocatalytic efficiency (nanocomposite dose, chloramine-T initial concentration, and reaction $\mathrm{pH}$ ) were analyzed in detail. Further, the antimicrobial activities of the prepared nanocomposite were tested and the effect of UV-activation on the antimicrobial abilities of the prepared nanocomposite was analyzed. Finally, a comparison between the antimicrobial abilities of the current nanocomposite and our previously-reported nanocomposite $\left(\mathrm{Co}_{x} \mathrm{Ni}_{1-x} \mathrm{Fe}_{2} \mathrm{O}_{4 i}\right.$ $\mathrm{x}=0.9 / \mathrm{SiO}_{2} / \mathrm{TiO}_{2}$ ) had been carried out. Our results revealed that the prepared nanocomposite possessed a high degree of crystallinity, confirmed by XRD, while UV-Vis. recorded an absorption peak at $299 \mathrm{~nm}$. In addition, the prepared nanocomposite possessed BET-surface area of $\left(28.29 \pm 0.19 \mathrm{~m}^{2} / \mathrm{g}\right)$ with narrow pore size distribution. Moreover, it had semi-spherical morphology, high-purity and an average particle size of $(19.0 \mathrm{~nm})$. The photocatalytic degradation efficiency was inverselyproportional to chloramine-T initial concentration and directly proportional to the photocatalyst dose. In addition, basic medium ( $\mathrm{pH} 9$ ) was the best suited for chloramine-T degradation. Moreover, UV-irradiation improved the antimicrobial abilities of the prepared nanocomposite against $E$. coli, $B$. cereus, and C. tropicalis after $60 \mathrm{~min}$. The observed antimicrobial abilities (high ZOI, low MIC and more efficient antibiofilm capabilities) were unique compared to our previously-reported nanocomposite. Our work offers significant insights into more efficient water treatment and fosters the ongoing efforts

${ }^{1}$ Department of Electrical and Electronic Information Engineering, Toyohashi University of Technology, 1-1 Hibarigaoka, Tempaku-cho, Toyohashi, Aichi 441-8580, Japan. ${ }^{2}$ Center for Nanotechnology (CNT), School of Engineering and Applied Sciences, Nile University, Sheikh Zayed 16453, Giza, Egypt. ${ }^{3}$ Drug Microbiology Lab, Drug Radiation Research Department, National Center for Radiation Research and Technology (NCRRT), Atomic Energy Authority, Cairo, Egypt. ${ }^{4}$ Chemical Engineering Department, Military Technical College (MTC), Egyptian Armed Forces, Cairo, Egypt. ${ }^{5}$ Institute of Liberal Arts and Sciences, Toyohashi University of Technology, 1-1 Hibarigaoka, Tempaku-cho, Toyohashi, Aichi 441-8580, Japan. ${ }^{6}$ These authors contributed equally: M. Abd Elkodous and Gharieb S. El-Sayyad. ${ }^{\boxplus}$ email: kawamura.go.km@tut.jp; matsuda.atsunori.hh@tut.jp 
looking at how pollutants degrade the water supply and the disinfection of water-borne pathogenic microorganisms.

Population growth, the continued demand of water and water shortages from one year to another are pushing the world towards a water shortage problem ${ }^{1-3}$. In addition, most of the available potable water on earth is contaminated with many kinds of pollutants such as organic, inorganic materials, heavy metals and pathogenic microorganisms, causing serious diseases ${ }^{4-7}$. Among these pollutants, chloramine- $\mathrm{T}$ is gaining a lot of attention due to its adverse effects on public health, and is seriously threatening the aquatic environment ${ }^{8,9}$. Chloramine-T is an organic compound with a chloro-substituent in the place of an amino hydrogen ${ }^{10}$. It is currently-used in many applications such as antifouling biocides, disinfectant, various food products, and different cosmetics ${ }^{11-13}$. However, several toxicological experiments have shown that chloramine- $\mathrm{T}$ is harmful to the skin and eyes of humans ${ }^{14}$. In addition, it causes irritation of the upper respiratory $\operatorname{tract}^{15}$ and in severe cases nausea, vomiting and diarrhea ${ }^{16}$. Thus, reduction and degradation of chloramine-T into relatively-safe intermediates is important for our environment. Currently, there are many water treatment and purification methods ${ }^{17-19}$. However, these traditional methods are not effective in terms of water quality, time of processing and overall cost of operation. Nanotechnology, through nanomaterials, offers not only more-effective ways of water purification, but also costeffective and easily-manipulated techniques. Nanomaterials possess outstanding chemical, physical and biological properties compared to their bulk materials, due to the large number of surface atoms compared to the inner mass $^{20-23}$. Recently, there are many reports highlighting various promising nano materials and composites for heavy metal adsorption and dye removal applications ${ }^{24-28}$. With respect to them, titanium dioxide nanoparticles $\left(\mathrm{TiO}_{2} \mathrm{NPs}\right.$ ) have been extensively- studied over the past decades (since water splitting by Fujishima and Honda in 1972) due to their cost-effectiveness, high degree of thermal and chemical stabilities, high-oxidizing ability, and their good electronic and optical characteristics ${ }^{29}$. $\mathrm{TiO}_{2} \mathrm{NPs}$ are very promising in many environmental applications like water treatment. However, the technological application of $\mathrm{TiO}_{2} \mathrm{NPs}$ is limited by two main drawbacks ${ }^{30}$. Firstly, they possess a wide energy bandgap $(2.96,3.02$ and $3.2 \mathrm{eV})$ for the brookite, rutile and anatase phases, respectively ${ }^{31}$. Thus, $\mathrm{TiO}_{2} \mathrm{NPs}$ are activated only by ultraviolet (UV) light, representing a tiny

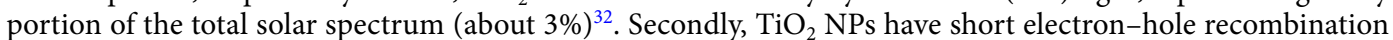
time (about $10^{-9} \mathrm{~s}$ ), while photocatalytic reactions need times at the order of $\left(10^{-3} \mathrm{~s}\right)$, that further deteriorates the photocatalytic efficiency of $\mathrm{TiO}_{2} \mathrm{NPs}^{33,34}$. Various tailoring methods have been reported for increasing the quantum efficiency of $\mathrm{TiO}_{2} \mathrm{NPs}$ such as the formation of mixed $\mathrm{TiO}_{2}$ phases which reduces the band gap energy ${ }^{35}$, doping with ions of non-metals like carbon ${ }^{36}$ and sulfur $^{37}$ and loading with noble metals like silver (Ag) ${ }^{38}$, platinum $(\mathrm{Pt})$ and gold $(\mathrm{Au})^{39}$ which elongate electron-hole recombination time. Currently, loading $\mathrm{TiO}_{2} \mathrm{NPs}$ with cheap carbon nanoparticles is gaining significant considerations, such as conjugation with activated carbon which improved the adsorption potential of $\mathrm{TiO}_{2} \mathrm{NPs}^{40}$. Additionally, loading with graphene and carbon nanotubes has shown to provide good electron mobility and reduced the recombination time of the photo-generated charge carriers $^{41,42}$. Recently, carbon dots (C-dots) have received much interest due to their strong photoluminescence, abundance, cost-effectiveness, ease of manipulation, and chemical inertness, and their role as electron reservoirs which elongates the electron-hole recombination time during photocatalytic degradation ${ }^{43-46}$.

In this study, single nanoparticles were incorporated into one nanocomposite to gain more benefits. A recyclable $\mathrm{TiO}_{2}$-based and C-dots-loaded nanocomposite $\left(\mathrm{Co}_{\mathrm{x}} \mathrm{Ni}_{1-\mathrm{x}} \mathrm{Fe}_{2} \mathrm{O}_{4} ; \mathrm{x}=0.9 / \mathrm{SiO}_{2} / \mathrm{TiO}_{2} / \mathrm{C}\right.$-dots $)$ was prepared by a layer-by-layer method. A magnetic core $\left(\mathrm{Co}_{\mathrm{x}} \mathrm{Ni}_{1-\mathrm{x}} \mathrm{Fe}_{2} \mathrm{O}_{4} ; \mathrm{x}=0.9\right)$ was formed to make the nanocomposite recyclable by magnetic separation, $\mathrm{SiO}_{2}$ layer was used as a protective shell for the $\mathrm{TiO}_{2} \mathrm{NPs}_{\text {(to }}$ protect the $\mathrm{TiO}_{2}$ NPs from the formation of pseudo-brookite due to magnetic core contact), anatase $\mathrm{TiO}_{2}$ shell was prepared as an efficient photocatalyst with good photocatalytic abilities, and C-dots were loaded onto the $\mathrm{TiO}_{2}$ surface to act as an electron reservoir to increase $\mathrm{TiO}_{2}$ quantum efficiency. The photocatalytic abilities of the prepared nanocomposite were tested against chloramine- $\mathrm{T}$ degradation (an organic compound). In addition, reaction kinetics, photocatalytic mechanism and different parameters affecting the efficiency of photodegradation (nanocomposite dose, chloramine- $\mathrm{T}$ initial concentration and reaction $\mathrm{pH}$ ) had been analyzed. Moreover, the antimicrobial activities of the synthesized nanocomposite had been tested against multi-drug- resistant bacteria and pathogenic fungi. Finally, the effect of UV-activation on the antimicrobial abilities of the prepared nanocomposite had been studied.

\section{Materials and methods}

Materials. Copper acetate monohydrate $\left(\mathrm{C}_{4} \mathrm{H}_{8} \mathrm{CuO}_{5}\right)$, ascorbic acid $\left(\mathrm{C}_{6} \mathrm{H}_{8} \mathrm{O}_{6}\right)$, titanium (IV) isopropoxide $97 \%\left(\mathrm{C}_{12} \mathrm{H}_{28} \mathrm{O}_{4} \mathrm{Ti}\right)$, ammonium hydroxide $28 \%\left(\mathrm{NH}_{4} \mathrm{OH}\right)$, tetraethyl orthosilicate (TEOS) $98 \%$ [ $\left.\mathrm{Si}\left(\mathrm{OC}_{2} \mathrm{H}_{5}\right)_{4}\right]$, absolute ethanol $99.9 \%\left(\mathrm{C}_{2} \mathrm{H}_{5} \mathrm{OH}\right)$, hydroxypropyl cellulose $(\mathrm{M} . \mathrm{W} .=80,000)$, nickel chloride $\left(\mathrm{NiCl}_{2}\right)$, cobalt chloride $\left(\mathrm{CoCl}_{2}\right)$, sodium hydroxide pellets $(\mathrm{NaOH})$, Ferric chloride hexahydrate $\left(\mathrm{FeCl}_{3} \cdot 6 \mathrm{H}_{2} \mathrm{O}\right)$, and chloramine- $\mathrm{T}$ trihydrate $\mathrm{C}_{7} \mathrm{H}_{7} \mathrm{ClNNaO}_{2} \mathrm{~S} \cdot 3 \mathrm{H}_{2} \mathrm{O}$ were purchased from Sigma Aldrich (Germany). All reagents were of extra-pure grade and were used as received without further purification.

Method. Preparation of the sandwich structure: $\left(\mathrm{Co}_{x} \mathrm{Ni}_{1-x} \mathrm{Fe}_{2} \mathrm{O}_{4} ; x=0.9 / \mathrm{SiO}_{2} / \mathrm{TiO}_{2}\right)$ nanocomposite. The detailed preparation steps are reported in our previously-published papers ${ }^{47,48}$.

Preparation of carbon nanoparticles (C-dots). C-dots were prepared according to the method reported by Xiaofang Jia et al. ${ }^{49}$. Briefly, $(6.8 \mathrm{~g})$ of ascorbic acid were dissolved in $(400 \mathrm{ml})$ deionized water (D.I.W.). $(0.8 \mathrm{~g})$ of copper acetate monohydrate was then added into the above solution, and the solution stirred at room temperature for $10 \mathrm{~min}$. The temperature was then raised to $90{ }^{\circ} \mathrm{C}$ and kept for $5 \mathrm{~h}$ and the remaining solution centrifuged 


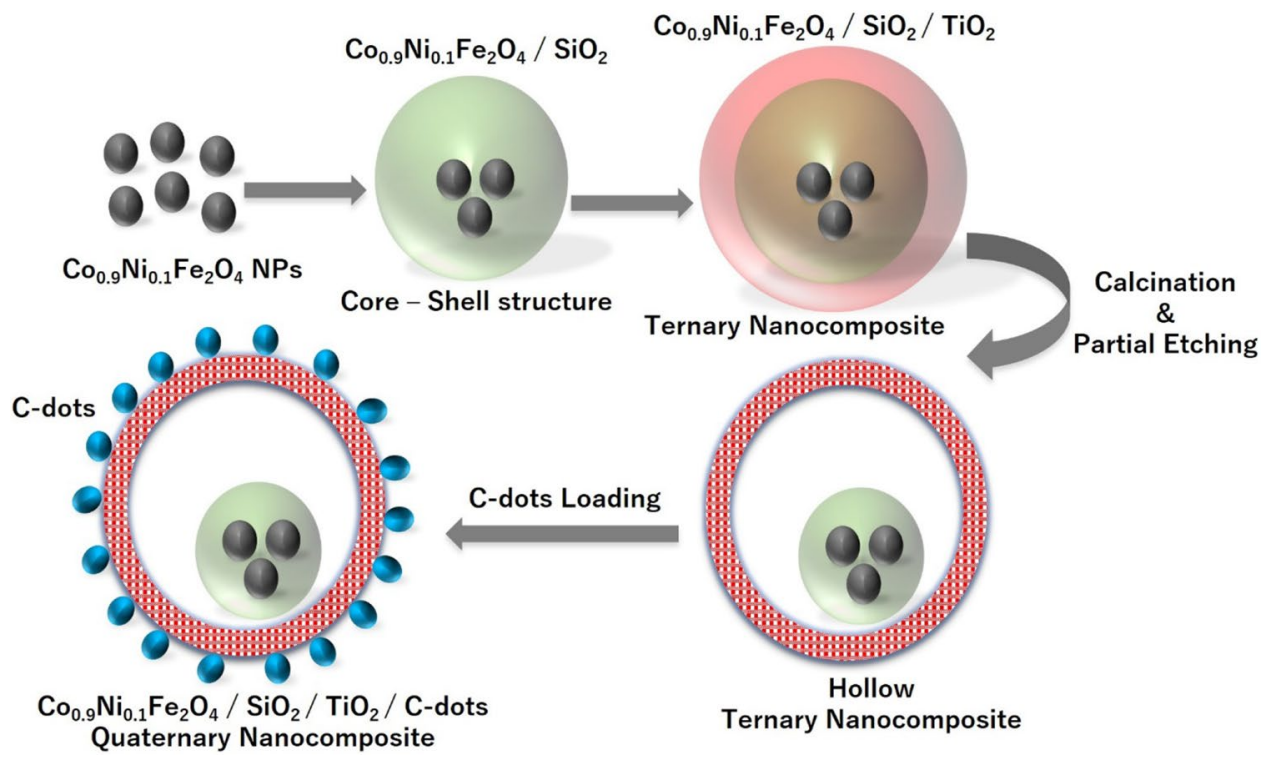

Figure 1. Schematic representation of the mechanism of $\mathrm{Co}_{\mathrm{x}} \mathrm{Ni}_{1-\mathrm{x}} \mathrm{Fe}_{2} \mathrm{O}_{4} ; \mathrm{x}=0.9 / \mathrm{SiO}_{2} / \mathrm{TiO}_{2} / \mathrm{C}$-dots nanocomposite formation.

at $9,000 \mathrm{rpm}$ for $20 \mathrm{~min}$ to remove large particles. Finally, the supernatant containing the C-dots was dried at $60{ }^{\circ} \mathrm{C}$ for $8 \mathrm{~h}$.

Preparation of $\left(\mathrm{Co}_{x} \mathrm{Ni}_{1-x} \mathrm{Fe}_{2} \mathrm{O}_{4} ; x=0.9 / \mathrm{SiO}_{2} / \mathrm{TiO}_{2} / \mathrm{C}\right.$-dots $)$ nanocomposite. The C-dots-loaded nanocomposite was prepared according to the method reported in our previously-published paper ${ }^{29}$. Briefly, $0.8 \mathrm{~g}$ of the nanocomposite from part (Preparation of the sandwich structure) was mixed with $0.1 \mathrm{~g}$ of C-dots from part (Preparation of carbon nanoparticles). Then, $50 \mathrm{ml}$ D.I.W was added, and the mixture dispersed using water-bath sonication for $45 \mathrm{~min}$. The hybrid composite was then centrifuged at 8,000 rpm for $15 \mathrm{~min}$. Finally, the collected composite was washed with D.I.W. and dried at $85^{\circ} \mathrm{C}$ for $2 \mathrm{~h}$. The preparation steps are schematically-represented in Fig. 1.

Characterization of the prepared nanocomposite. Crystallinity and phase were studied using X-ray diffraction (XRD) analysis on an Ultima IVX-ray diffractometer, Rigaku, Japan, applying a voltage of $40 \mathrm{kV}$, a current of $30 \mathrm{~mA}$ and $\mathrm{Cu} \mathrm{K}$ radiation $(\lambda=1.540598 \AA$ ). UV-Vis. absorption was calculated via a V-670 spectrophotometer, JASCO, Japan. BET and BJH analyses were used to determine surface area and pore size distribution via Tristar II Micromeritics, Japan. The average particle size was determined by a high-resolution transmission electron microscope (HR-TEM), JEM-2100 F, JEOL Ltd., Japan. The morphology, elemental composition and purity of the particles were analyzed by scanning electron microscope (SEM) supported with an energy-dispersive X-ray (EDX) unit, SU8000 Type II, HITACHI high technologies, Japan. FTIR analysis was carried out by an FT-IR 3600 , JASCO Infra-Red spectrometer via the $\mathrm{KBr}$ pellet method. It was recorded through a wave-number scale from 4,000 to $400 \mathrm{~cm}^{-1}$.

Photocatalytic activity of $\left(\mathrm{Co}_{x} \mathrm{Ni}_{1-x} \mathrm{Fe}_{2} \mathrm{O}_{4} ; x=0.9 / \mathrm{SiO}_{2} / \mathrm{TiO}_{2} / \mathrm{C}\right.$-dots $)$ nanocomposite against chloramine- $\mathrm{T}$ trihydrate. Photocatalytic experiments were carried out at an ambient temperature of $24 \pm 2{ }^{\circ} \mathrm{C}$. A fixed amount of $10 \mathrm{mg}$ of the synthesized nanocomposite was added to a $50 \mathrm{~mL}$ aqueous solution of chloramine $-\mathrm{T}\left(\mathrm{C}_{\mathrm{o}}=10 \mathrm{mg} / \mathrm{l}\right)$ and stirred for $2 \mathrm{~h}$. in the dark. After reaching adsorption-desorption equilibrium, the suspension was illuminated by a low-pressure, $10 \mathrm{~W}$ mercury lamp with $90 \%$ emittance at $254 \mathrm{~nm}$. The lamp was axially-located and held in a quartz immersion tube. At given irradiation time intervals, $1 \mathrm{ml}$ of the suspension was taken out by a syringe equipped with $2.5 \mu \mathrm{m}$ pore size filter. The filtered supernatant was centrifuged at $(5,000 \mathrm{rpm})$ for (10 $\mathrm{min})$, to remove particles of the employed photocatalyst. The changes in chloramine-T concentration during photo-decomposition were determined by measuring the absorbance at $\lambda_{\max }=225 \mathrm{~nm}$ as a function of irradiation time in the liquid cuvette configuration. D.I.W. was used as the reference on a UV-Vis. spectrophotometer (Agilent Technologies Cary 60 UV-Vis.). The concentration of chloramine-T prior to UV-irradiation was used as the initial value for the measurement of chloramine-T degradation.

Antimicrobial activity of $\mathrm{C}$-dots and $\mathrm{Co}_{x} \mathrm{Ni}_{1}-x \mathrm{Fe}_{2} \mathrm{O}_{4} ; x=0.9 / \mathrm{SiO}_{2} / \mathrm{TiO}_{2} / \mathrm{C}$-dots nanocomposite. Both C-dots and $\mathrm{Co}_{\mathrm{x}} \mathrm{Ni}_{1-\mathrm{x}} \mathrm{Fe}_{2} \mathrm{O}_{4} ; \mathrm{x}=0.9 / \mathrm{SiO}_{2} / \mathrm{TiO}_{2} / \mathrm{C}$-dots nanocomposite were dispersed in DMSO to form two tested concentrations for each sample $(10$ and $15 \mu \mathrm{g} / \mathrm{ml})$. Next, their antimicrobial activities were individually-tested using the agar well diffusion method ${ }^{50}$, against different isolates of infection-causing bacteria such as Staphylococcus aureus (MRSA), Escherichia coli, Bacillus cereus, Pseudomonas aeruginosa, and Klebsiella pneumoniae. Further- 
more, the antifungal potentials of both samples were checked against unicellular pathogenic fungi (Candida tropicalis and Candida albicans). The tested microorganisms were kindly-gifted from the culture collection of Drug Microbiology Lab., Drug Radiation Research Dep., NCRRT, Cairo, Egypt.

It is worth stating that $0.5 \mathrm{McFarland}$ standard of all tested bacterial inoculums was fixed at $3-4 \times 10^{8} \mathrm{CFU} /$ $\mathrm{ml}$ and $2-5 \times 10^{8} \mathrm{CFU} / \mathrm{ml}$ for pathogenic yeast. Growth restraint of the examined pathogenic bacteria and yeast was defined by measuring the zone of inhibition (ZOI) after $24 \mathrm{~h}$. of incubation ${ }^{51}$.

In addition, conventional antibiotic discs such as nystatin (NS), with $6 \mathrm{~mm}$-diameter, and a ready-to-use solution of Amoxicillin/Clavulanic acid (AMC, $100 \mu \mathrm{g} / \mathrm{ml}$ ) were utilized as references to compare the abilities of the developed nanocomposite ${ }^{52}$.

A minimum inhibitory concentration (MIC) was defined using Luria-Bertani (LB) broth with suitable serial dilution ${ }^{53,54}$. A test tube containing the selected microorganism and the nutrient was employed as a positive control, and another tube with just the nutrient was used as a negative control. C-dots and the prepared C-dots loaded-nanocomposite (beginning with a concentration of $50 \mathrm{mg} / \mathrm{ml}$ ) were examined to determine their MIC values. MIC values were measured after $24 \mathrm{~h}$. of incubation at $37^{\circ} \mathrm{C}^{55,56}$. The examined bacterial inoculums were fixed at $3-5 \times 10^{8} \mathrm{CFU} / \mathrm{ml}$, while Candida species were fixed at $2-5 \times 10^{7} \mathrm{CFU} / \mathrm{ml}$. MIC values were determined by ELISA plate reader at absorption wavelength of $600 \mathrm{~nm}^{56,57}$.

Antibiofilm activity of $\mathrm{Co}_{x} \mathrm{Ni}_{1-x} \mathrm{Fe}_{2} \mathrm{O}_{4} ; x=0.9 / \mathrm{SiO}_{2} / \mathrm{TiO}_{2} / \mathrm{C}$-dots nanocomposite. A semi-quantitative investigation of biofilm growth by pathogenic bacteria and yeast and its inhibition by the prepared C-dots loaded nanocomposite were evaluated according to the process described by Christensen et al. ${ }^{58}$. The apparent detection of biofilms created by pathogenic bacteria and yeast throughout the inner walls of test tubes having the tested nanocomposite with a concentration of $(15 \mu \mathrm{g} / \mathrm{ml})$ and tubes without the nanocomposite (control) was carried out.

Additionally, nutrient broth $(5 \mathrm{ml})$ was added to all test tubes after setting $0.5 \mathrm{McFarland}$ standards at $2-3 \times 10^{7} \mathrm{CFU} / \mathrm{ml}$ (for the tested bacteria). The tubes were then incubated for $24 \mathrm{~h}$. at $37^{\circ} \mathrm{C}$. The content of the control tubes and nanocomposite-included tubes was discarded and tubes were washed and cleaned with phosphate buffer saline (PBS, $\mathrm{pH}=7.4$ ). After that, tubes were dried ${ }^{48,59}$. The developed yeast and bacterial biofilms were fixed by $5 \mathrm{ml}$ sodium acetate (3\%) for $15 \mathrm{~min}$, and then all tubes were washed with D.I.W. Bacterial and yeast biofilms were dyed with $0.1 \%$ crystal violet (CV) for $10 \mathrm{~min}$, then D.I.W. used to eliminate the excess quantity of $\mathrm{CV}^{60}$. Additionally, $4 \mathrm{ml}$ of absolute ethanol was employed to dissolve $\mathrm{CV}$. The formed biofilms were identified by the characteristic stained rings around the walls of test tubes ${ }^{61}$. The bacterial and yeast biofilms were investigated using a UV-Vis. spectrophotometer at $570 \mathrm{~nm}$, and the biofilm suppression percentage (\%) was determined by utilizing Eq. $(1)^{48,62}$.

Percentage of bacterial and yeast biofilm inhibition(\%) $=\frac{\text { O.D. of the control sample }- \text { O.D. of the treated sample }}{\text { O.D. of the control sample }} \times 100$

Effect of UV-irradiation on the antimicrobial abilities of the prepared nanocomposite. To distinguish the influence of UV-irradiation on the antimicrobial potential of the synthesized $\mathrm{Co}_{\mathrm{x}} \mathrm{Ni}_{1-\mathrm{x}} \mathrm{Fe}_{2} \mathrm{O}_{4} ; \mathrm{x}=0.9 / \mathrm{SiO}_{2} / \mathrm{TiO}_{2} / \mathrm{C}$ dots nanocomposite against microbes, the restraint percentage was defined by measuring the optical density of the viable and dead microbial cells ${ }^{63}$. Three susceptible microbes were selected, including E. coli (Gram-negative bacteria), B. cereus (Gram-positive bacteria) and C. tropicalis (unicellular fungi). For each microorganism, four test tubes were prepared. The first tube was a control, which contained tested microbes and was not UV-irradiated; the second had both tested microbes and the prepared nanocomposite and was not UV-irradiated; the third contained the tested microbes and was UV-irradiated; and the fourth included both tested microbes and the synthesized nanocomposite, and was UV-irradiated.

All four tubes had nutrient broth and a fixed number of microorganisms (0.5 McFarland, CFU/ml). A lowpressure mercury lamp emitting UV (10 W, 90\% emittance at $254 \mathrm{~nm})$ was horizontally-positioned and settled on the laminar flow. Examined tubes were subjected to UV-irradiation for $1 \mathrm{~h}$ at a distance of about $60.96 \mathrm{~cm}$.

It is worth to mention that the number of bacteria and yeast was determined every $10 \mathrm{~min}$ through a UV-Vis. spectrophotometer, at a wavelength of $600 \mathrm{~nm}$ for bacteria and $630 \mathrm{~nm}$ for Candida species, for $1 \mathrm{~h}$ and the repression percentage \% was estimated by Eq. (1).

Reaction mechanism using SEM/EDX analysis of nanocomposite-treated microbial cells. Obtained bacterial and Candida cells from the biofilm-forming test were washed with PBS and fixed with 3\% glutaraldehyde solution. The preserved bacterial and Candida specimens were regularly-washed with PBS and evenly-dehydrated with various concentrations of ethanol $(30 \%, 50 \%, 70 \%, 80 \%, 95 \%$, and $100 \%)$ for about $20 \mathrm{~min}$ at $28 \pm 2{ }^{\circ} \mathrm{C}^{59}$. Next, bacterial and Candida cells were placed on an aluminum scrap for SEM/EDX analysis ${ }^{59}$. The morphological characteristics of the control (non-treated pathogenic bacteria and yeast) and nanocomposite-treated bacterial and yeast cells were observed using SEM/EDX analysis.

Statistical analysis. Statistical interpretation of our results was performed through the ONE-WAY ANOVA analysis (at $\mathrm{P}<0.05$ ), using Duncan's multiple series studies, and the least significant difference (LSD) record $^{64}$. The obtained results were also analyzed by SPSS software (version 15). 


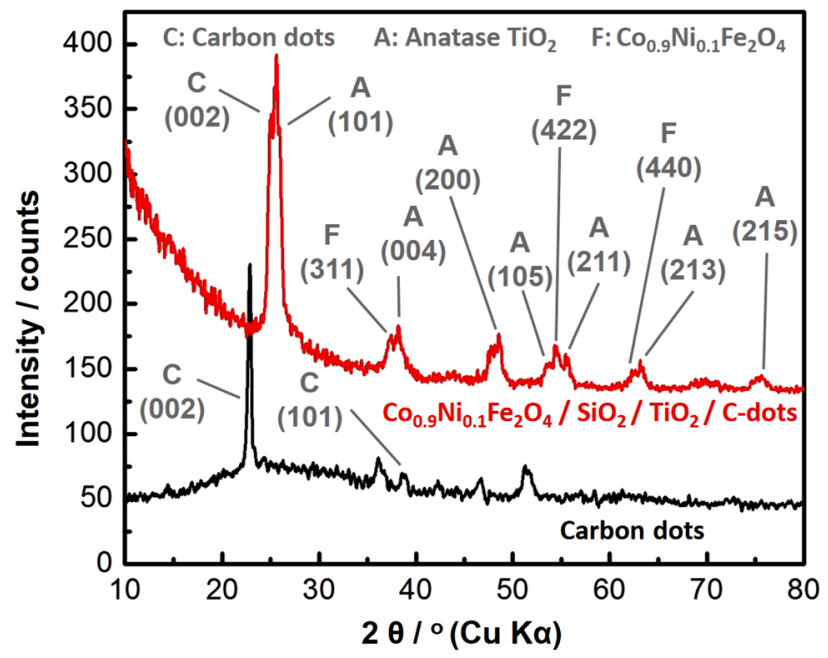

Figure 2. XRD patterns of the prepared C-dots $\mathrm{NPs}$ and $\mathrm{Co}_{\mathrm{x}} \mathrm{Ni}_{1-\mathrm{x}} \mathrm{Fe}_{2} \mathrm{O}_{4} ; \mathrm{x}=0.9 / \mathrm{SiO}_{2} / \mathrm{TiO}_{2} / \mathrm{C}$-dots nanocomposite.

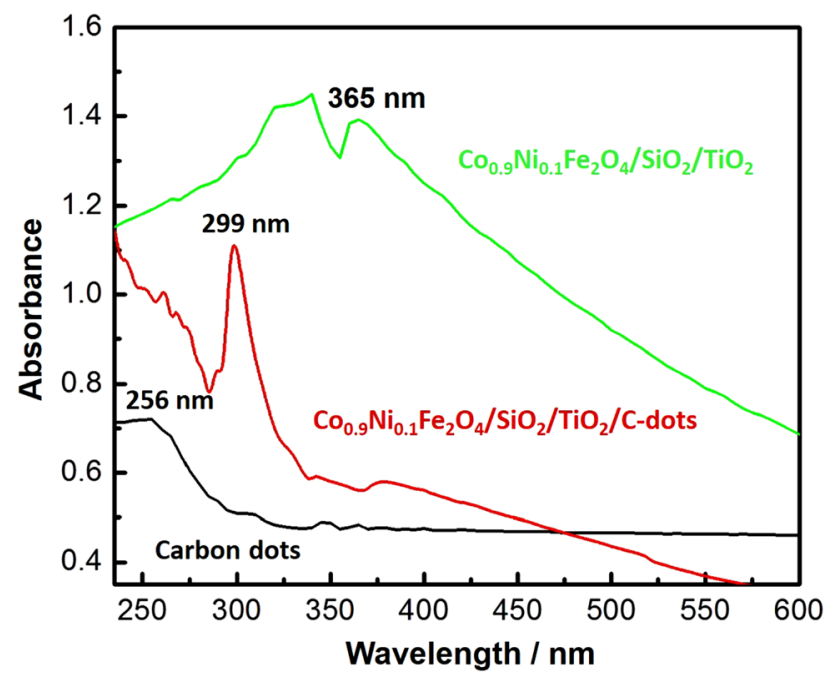

Figure 3. UV-Vis. absorption spectra of the prepared $\mathrm{Co}_{\mathrm{x}} \mathrm{Ni}_{1-\mathrm{x}} \mathrm{Fe}_{2} \mathrm{O}_{4} ; \mathrm{x}=0.9 / \mathrm{SiO}_{2} / \mathrm{TiO}_{2} / \mathrm{C}$-dots nanocomposite, bare C-dots and $\mathrm{Co}_{\mathrm{x}} \mathrm{Ni}_{1-\mathrm{x}} \mathrm{Fe}_{2} \mathrm{O}_{4} ; \mathrm{x}=0.9 / \mathrm{SiO}_{2} / \mathrm{TiO}_{2}$ nanocomposite.

\section{Results and discussion}

Characterization of the prepared $\mathrm{Co}_{x} \mathrm{Ni}_{1-x} \mathrm{Fe}_{2} \mathrm{O}_{4} ; \mathrm{x}=0.9 / \mathrm{SiO} / \mathrm{TiO}_{2} / \mathrm{C}$-dots nanocomposite. XRD analysis. Crystallinity and phase of the prepared C-dots and the whole nanocomposite were studied using XRD, as depicted in Fig. 2. Several diffraction peaks were recorded, such as the peak at $2 \theta=22.9^{\circ}$, plane (002), which corresponds to the C-dots as shown in Fig. $2^{65}$, while peaks recorded at $2 \theta=25.5^{\circ}$, plane (101), 38. $1^{\circ}$, plane (004), $48.4^{\circ}$, plane (200), 53.6 $6^{\circ}$, plane (105), $55.4^{\circ}$, plane (211), $63.1^{\circ}$, plane (213), and $75.6^{\circ}$, plane (215) correspond to anatase $\mathrm{TiO}_{2}$ NPs (JCPDS 21-1272). In addition, peaks observed at $2 \theta=37.2^{\circ}$, plane (311), $54.3^{\circ}$, plane (422), and $62.3^{\circ}$, plane (440) were due to the cobalt and nickel ferrite of $\mathrm{Co}_{\mathrm{x}} \mathrm{Ni}_{1-\mathrm{x}} \mathrm{Fe}_{2} \mathrm{O}_{4} ; \mathrm{X}=0.9$ NPs (JCPDS 10-325 and JCPDS 1-1121). It is worth mentioning that an $\mathrm{SiO}_{2}$ amorphous halo was suppressed due to the high intensity of $\mathrm{C}$-dots and $\mathrm{TiO}_{2}$ peaks, as previously-reported in our paper ${ }^{48}$.

UV-Vis. spectroscopic analysis and bandgap calculation. To reveal the optical characteristics of the synthesized nanocomposite and bare C-dots, UV-Vis. analysis was carried out, as shown in Fig. 3. A strong absorption peak at $(299 \mathrm{~nm})$ was recorded for the prepared $\mathrm{Co}_{\mathrm{x}} \mathrm{Ni}_{1-\mathrm{x}} \mathrm{Fe}_{2} \mathrm{O}_{4} ; \mathrm{x}=0.9 / \mathrm{SiO}_{2} / \mathrm{TiO}_{2} / \mathrm{C}$-dots nanocomposite. While a C-dots absorption peak was recorded at $(256 \mathrm{~nm})$, this could be attributed to $\pi \rightarrow \pi^{*}$ transitions of carbon ${ }^{66}$. It is worth mentioning that the loading of $\mathrm{C}$-dots resulted in a change of the nanocomposite absorption from $\left(365 \mathrm{~nm}\right.$ ) for the previously-prepared $\mathrm{Co}_{\mathrm{x}} \mathrm{Ni}_{1-\mathrm{x}} \mathrm{Fe}_{2} \mathrm{O}_{4} ; \mathrm{x}=0.9 / \mathrm{SiO}_{2} / \mathrm{TiO}_{2}$ nanocomposite to (299 $\mathrm{nm}$ ) for the newly-prepared C-dots-loaded $\mathrm{Co}_{\mathrm{x}} \mathrm{Ni}_{1-\mathrm{x}} \mathrm{Fe}_{2} \mathrm{O}_{4} ; \mathrm{x}=0.9 / \mathrm{SiO}_{2} / \mathrm{TiO}_{2}$ nanocomposite ${ }^{48}$. This shift could be attributed 

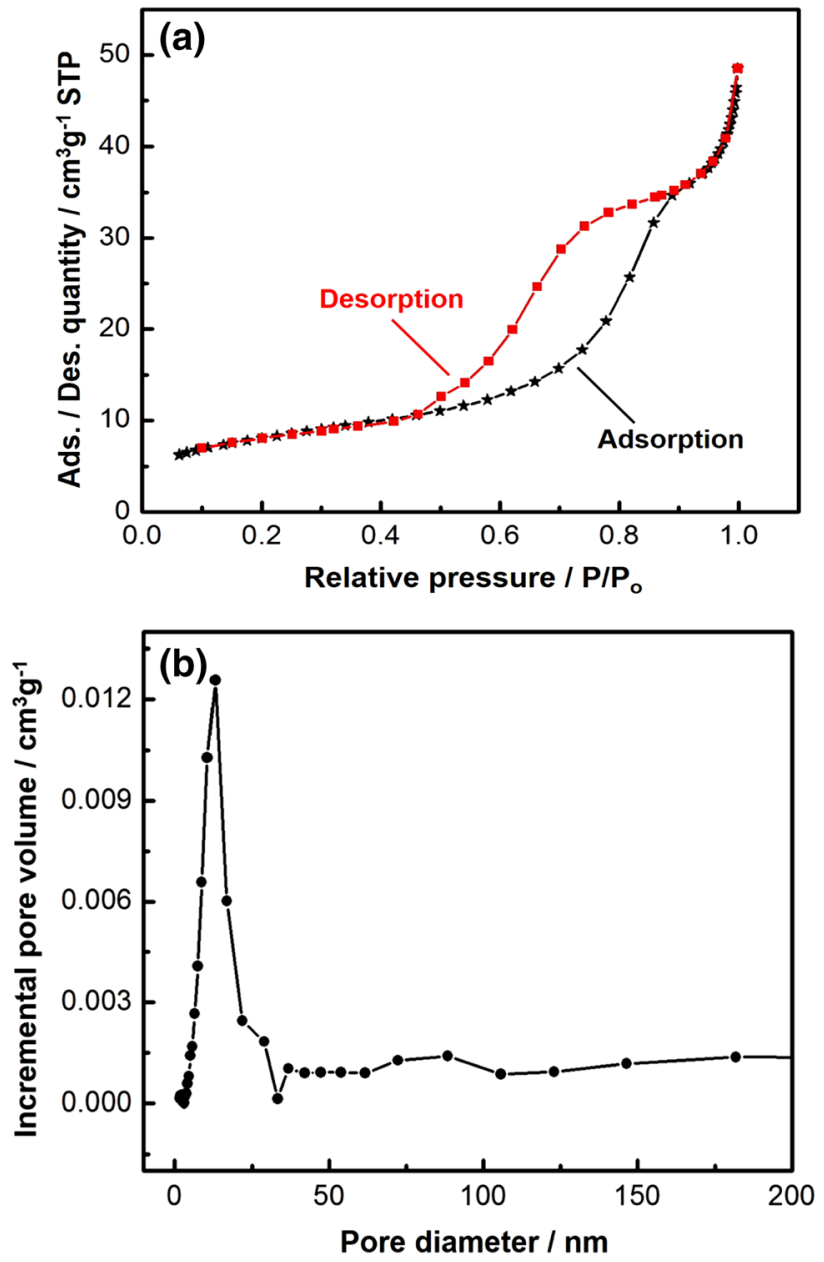

Figure 4. (a) $\mathrm{N}_{2}$ Adsorption-desorption isotherm of the prepared $\mathrm{Co}_{\mathrm{x}} \mathrm{Ni}_{1-\mathrm{x}} \mathrm{Fe}_{2} \mathrm{O}_{4} ; \mathrm{x}=0.9 / \mathrm{SiO}_{2} / \mathrm{TiO}_{2} / \mathrm{C}$-dots nanocomposite; (b) Pore size distribution.

to the existence of the new transition electronic bands due to loading with carbon ${ }^{67,68}$. While, band gap energy of the prepared nanocomposite was determined using Tauc's equation as follows (Eq. 2):

$$
\alpha \mathrm{h} v=\mathrm{A}(\mathrm{h} v-\mathrm{Eg})^{n}
$$

where $(\alpha)$ denotes the absorption coefficient, $(\mathrm{hv})$ represents photon energy, (A and $\mathrm{h}$ ) are constants, $(\mathrm{Eg})$ is the band gap energy and $(n)$ is a constant depends on the type of electronic transition and $n=1 / 2$, in case of indirect band gap semiconductors. By plotting a graph of (ahv) 1/2 versus hv, linear region's extrapolation gives the value of band gap energy $(\mathrm{Eg})$ as shown in supplementary Fig. 2. The calculated band gap energy of the synthesized nanocomposite has been found to be $(3.35 \mathrm{eV})$.

Surface area and pore size distribution analysis. $\quad \mathrm{N}_{2}$ adsorption-desorption isotherm and pore size distribution of the prepared nanocomposite are shown in Fig. 4a,b. According to the IUPAC classification, the obtained isotherm was of type (IV), indicating the presence of mesopores. The uptake of adsorbate was increased when pores became filled, and an inflection point occurred near the completion of the first monolayer ${ }^{69-71}$. In addition, sharp capillary condensation was recorded at higher pressures (0.95-1), which indicated the presence of macropores ${ }^{48,72}$. The calculated surface area of the prepared nanocomposite was $28.29 \pm 0.19 \mathrm{~m}^{2} / \mathrm{g}$ and pore volume was $0.001253 \mathrm{~cm}^{3} / \mathrm{g}$. Finally, Fig. $4 \mathrm{~b}$ shows the pore size distribution of the prepared nanocomposite. The prepared nanocomposite possessed unimodal and narrow pore size distribution, with an intense peak at (pore diameter $=13.3 \mathrm{~nm}$ ), confirming the presence of mesopores.

TEM, HR-TEM analysis and average particle size calculation. A TEM image of the prepared nanocomposite is shown in Fig. 5a. The primary particles were agglomerated with high interparticle void content. This structure was in good agreement with the $\mathrm{N}_{2}$-gas adsorption-desorption isotherm shown in Fig. 4a, where condensation in interparticle voids clearly-appeared at the high relative pressure region of $0.95-1$. In addition, the agglomeration mainly occurred during TEM sample preparation, since the nanocomposite was well-dispersed in water sol- 

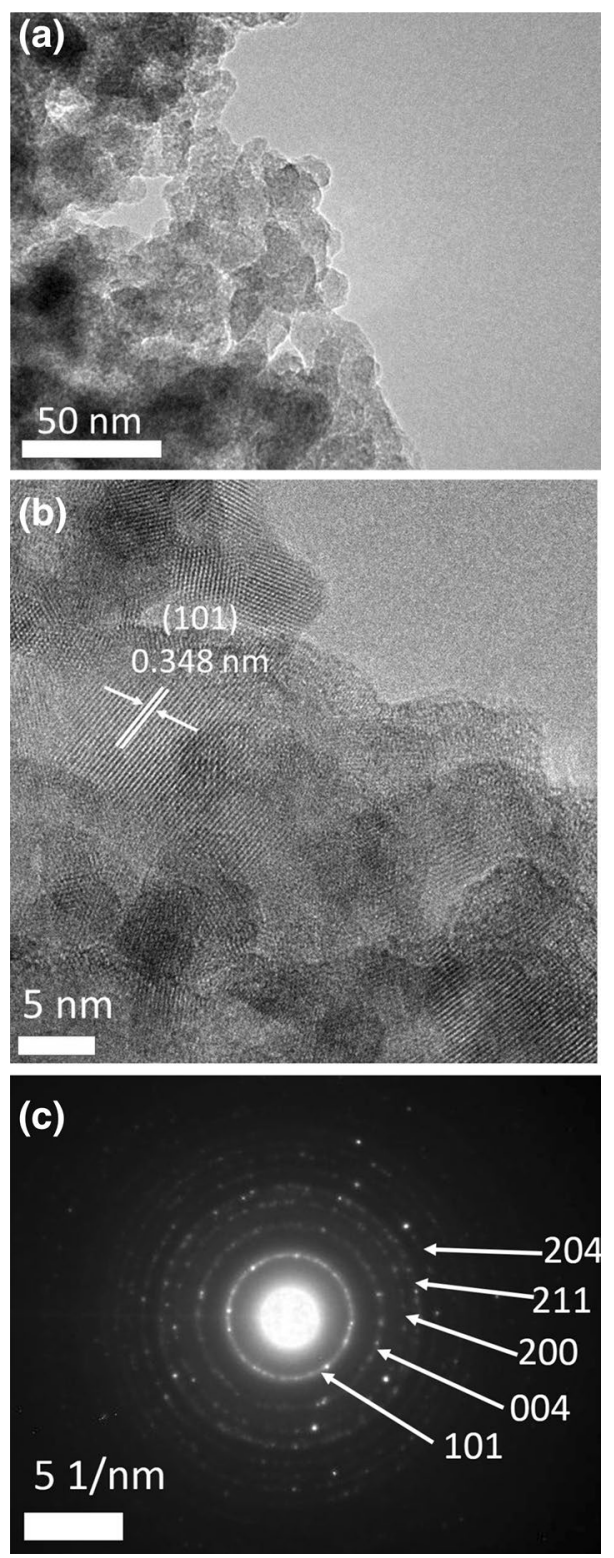

Figure 5. (a) TEM image of the prepared $\mathrm{Co}_{\mathrm{x}} \mathrm{Ni}_{1-\mathrm{x}} \mathrm{Fe}_{2} \mathrm{O}_{4} ; \mathrm{x}=0.9 / \mathrm{SiO}_{2} / \mathrm{TiO}_{2} / \mathrm{C}$-dots nanocomposite; (b) HR-TEM image; (c) SAED pattern.

vent and no precipitation was observed for several hours. The HR-TEM image in Fig. 5b shows that the average

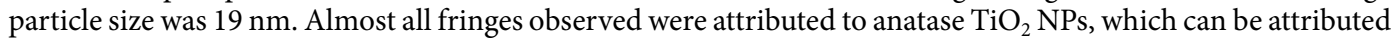
to the high content and crystallinity of $\mathrm{TiO}_{2}$, as shown in Fig. 6c. The selected area electron diffraction pattern in Fig. $5 \mathrm{c}$ also showed only the characteristic rings of anatase $\mathrm{TiO}_{2}$. This result was a good match to the recorded XRD pattern in Fig. 2b, where anatase $\mathrm{TiO}_{2}$ was the predominant crystal phase of the prepared nanocomposite.

SEM and EDX analysis. The external morphology, purity, and the elemental composition of the prepared nanocomposite were studied, as shown in Fig. 6a-c. SEM analysis showed that the prepared nanocomposite had a semi-spherical structure, with a uniform distribution of each layer. EDX analysis revealed the high purity of the prepared nanocomposite, as indicated by the presence of atoms characteristic to each component of it and the absence of foreign atoms that may appear as impurity.

Surface bonding and functional groups analysis; FTIR analysis of the prepared nanocomposite. Inducing chemical compounds via IR wave's causes either stretching or bending of these bonds and FT-IR was used to identify the functional groups and define the molecular structure of the studied nanocomposite. The FT-IR investigation was directed to determine the interaction between $\mathrm{Co}_{\mathrm{x}} \mathrm{Ni}_{1-\mathrm{x}} \mathrm{Fe}_{2} \mathrm{O}_{4} ; \mathrm{x}=0.9 / \mathrm{SiO}_{2} / \mathrm{TiO}_{2} /$ nanocomposite and the synthesized C-dots (Fig. 7). The observed bands around $455.7 \mathrm{~cm}^{-1}$ (in both $\mathrm{Co}_{\mathrm{x}} \mathrm{Ni}_{1-\mathrm{x}} \mathrm{Fe}_{2} \mathrm{O}_{4} ; \mathrm{x}=0.9 / \mathrm{SiO}_{2} / \mathrm{TiO}_{2} /$ nanocomposite and $\mathrm{Co}_{\mathrm{x}} \mathrm{Ni}_{1-\mathrm{x}} \mathrm{Fe}_{2} \mathrm{O}_{4} ; \mathrm{x}=0.9 / \mathrm{SiO}_{2} / \mathrm{TiO}_{2} / \mathrm{C}$-dots nanocomposite) were assigned to Ti-O stretching 

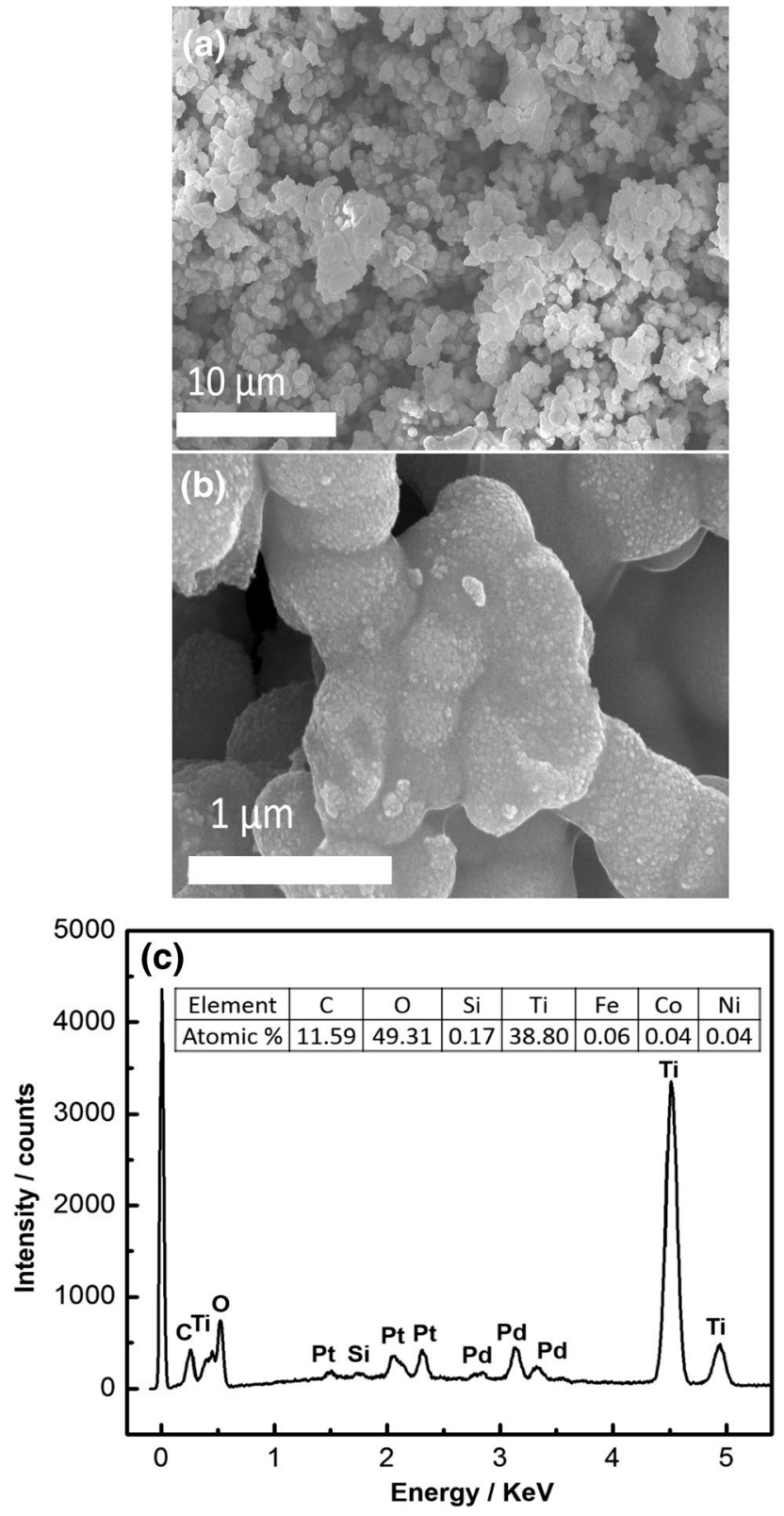

Figure 6. (a) $\mathrm{SEM}$ image of the prepared $\mathrm{Co}_{\mathrm{x}} \mathrm{Ni}_{1-\mathrm{x}} \mathrm{Fe}_{2} \mathrm{O}_{4} ; \mathrm{x}=0.9 / \mathrm{SiO}_{2} / \mathrm{TiO}_{2} / \mathrm{C}$-dots nanocomposite; (b) Magnified SEM image; (c) EDX pattern with elemental composition.

vibration $^{73}$. The presence of free silanol $(\mathrm{Si}-\mathrm{OH})$ groups on surface was detected at $920.25 \mathrm{~cm}^{-174,75}$. In addition, the symmetrical tension of $\mathrm{O}-\mathrm{Si}-\mathrm{O}$ appeared at $789.21 \mathrm{~cm}^{-1}$ while the bending of $\mathrm{Si}-\mathrm{O}$ could be seen at $455.7 \mathrm{~cm}^{-176}$. It is generally known that the spinel ferrites exhibit two FTIR active bands, designated as $v_{1}$ and $v_{2}$. The ' $v_{1}$ ' was observed at the range $\left(550-600 \mathrm{~cm}^{-1}\right)$ and ' $v_{2}$ ' was recorded at the range $\left(350-450 \mathrm{~cm}^{-1}\right)$. These two bands refer to the stretching of metal ions and oxygen bonds in the tetrahedral and octahedral sites, respectively ${ }^{77}$. Further, the cubic spinal phase of the present samples was successfully-formed ${ }^{78-81}$, as shown in Fig. 7.

The peaks at wavenumber $1155 \mathrm{~cm}^{-1}$ were attributed to a bond formation during the synthesis of cobalt nickel ferrite. The stretching of $\mathrm{O}-\mathrm{H}$ bands can be seen around $1561 \mathrm{~cm}^{-1}$. It is clear that the structure remained in the cubic spinel phase even after the substitution of metals on ferrite nanostructures.

It should be noted that, in the FTIR spectrum of the synthesized C-dots, the stretching vibration band of $\mathrm{C}=\mathrm{O}$ was observed at $1633.3 \mathrm{~cm}^{-1}$ (C-dots) and at $1675.0 \mathrm{~cm}^{-1}\left(\mathrm{Co}_{\mathrm{x}} \mathrm{Ni}_{1-\mathrm{x}} \mathrm{Fe}_{2} \mathrm{O}_{4} ; \mathrm{x}=0.9 / \mathrm{SiO}_{2} / \mathrm{TiO}_{2} / \mathrm{C}\right.$-dots nanocomposite), and the stretching vibration bands of $\mathrm{C}-\mathrm{O}$ was detected at $1099 \mathrm{~cm}^{-1}$ (C-dots) and at $1089.2 \mathrm{~cm}^{-1}$ $\left(\mathrm{Co}_{\mathrm{x}} \mathrm{Ni}_{1-\mathrm{x}} \mathrm{Fe}_{2} \mathrm{O}_{4} ; \mathrm{X}=0.9 / \mathrm{SiO}_{2} / \mathrm{TiO}_{2} / \mathrm{C} \text {-dots nanocomposite }\right)^{82}$. Moreover, the obvious two sharp peaks, at $1359 \mathrm{~cm}^{-1}$ (C-dots), $1362 \mathrm{~cm}^{-1}\left(\mathrm{Co}_{\mathrm{x}} \mathrm{Ni}_{1-\mathrm{x}} \mathrm{Fe}_{2} \mathrm{O}_{4} ; \mathrm{x}=0.9 / \mathrm{SiO}_{2} / \mathrm{TiO}_{2} / \mathrm{C}\right.$-dots nanocomposite) and $818.2 \mathrm{~cm}^{-1}$ (C-dots), 


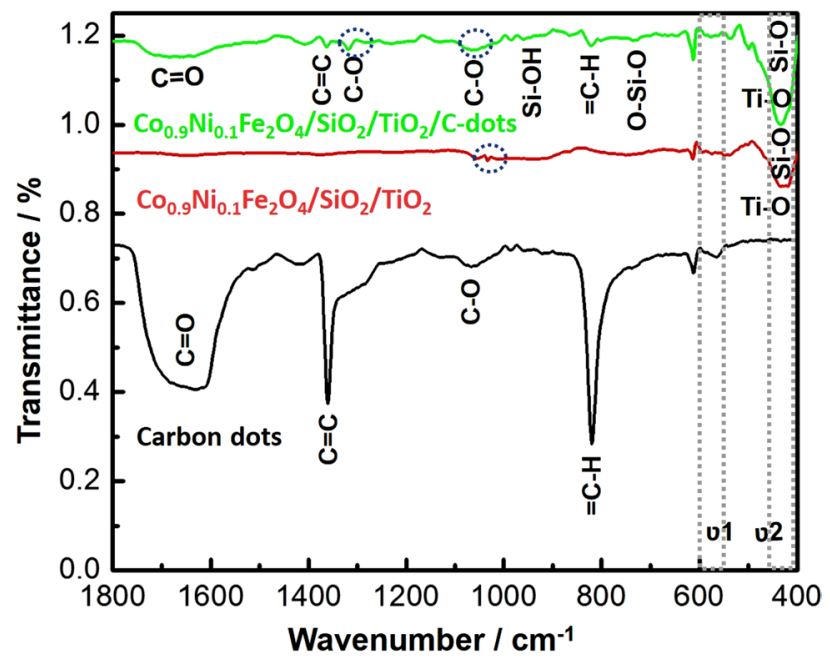

Figure 7. FTIR analysis of the $\mathrm{Co}_{\mathrm{x}} \mathrm{Ni}_{1-\mathrm{x}} \mathrm{Fe}_{2} \mathrm{O}_{4} ; \mathrm{x}=0.9 / \mathrm{SiO}_{2} / \mathrm{TiO}_{2} / \mathrm{C}$-dots nanocomposite, bare C-dots and $\mathrm{Co}_{\mathrm{x}} \mathrm{Ni}_{1-\mathrm{x}} \mathrm{Fe}_{2} \mathrm{O}_{4} ; \mathrm{x}=0.9 / \mathrm{SiO}_{2} / \mathrm{TiO}_{2}$ nanocomposite.

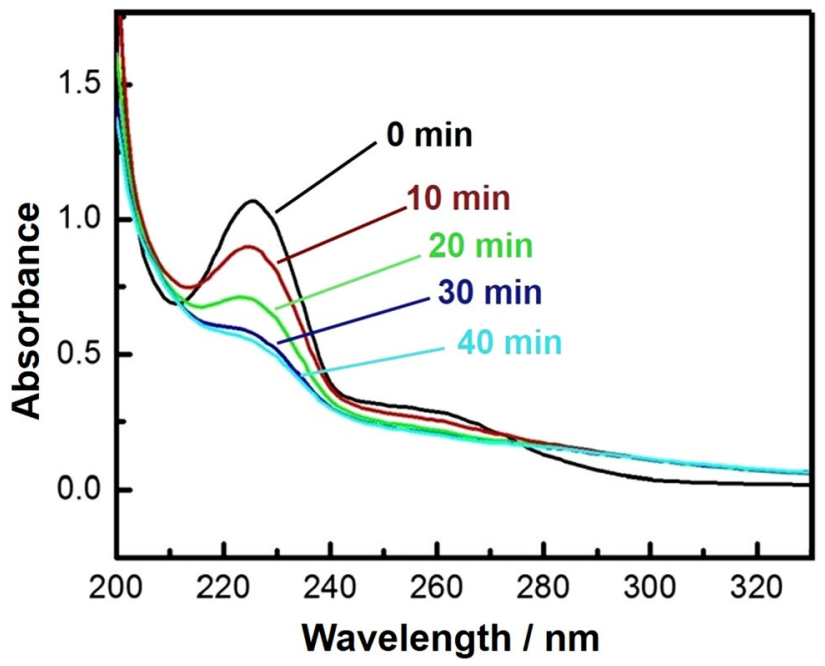

Figure 8. UV-Vis. spectra of chloramine-T solution after photodegradation test for $0-40 \mathrm{~min}(10 \mathrm{mg}$ of nanocomposite, $50 \mathrm{ml}$ chloramine-T solution, Temp. $=25^{\circ} \mathrm{C}$ and $\mathrm{pH} 7$ ).

$824.12 \mathrm{~cm}^{-1}\left(\mathrm{Co}_{\mathrm{x}} \mathrm{Ni}_{1-\mathrm{x}} \mathrm{Fe}_{2} \mathrm{O}_{4} ; \mathrm{x}=0.9 / \mathrm{SiO}_{2} / \mathrm{TiO}_{2} / \mathrm{C}\right.$-dots nanocomposite), were associated with the stretching and bending vibrations of $\mathrm{C}=\mathrm{C}$, and $=\mathrm{C}-\mathrm{H}$, respectively, which suggested the presence of alkyl groups ${ }^{83}$.

Finally, one distinct peak, located at $1319.7 \mathrm{~cm}^{-1}$ in $\mathrm{Co}_{\mathrm{x}} \mathrm{Ni}_{1-\mathrm{x}} \mathrm{Fe}_{2} \mathrm{O}_{4} ; \mathrm{x}=0.9 / \mathrm{SiO}_{2} / \mathrm{TiO}_{2} / \mathrm{C}$-dots nanocomposite, was not detected in $\mathrm{C}$-dots spectrum. It may have corresponded to the $\mathrm{C}-\mathrm{O}$ functional group, which suggested the conjugation of $\mathrm{C}$ atom with $\mathrm{O}$ atoms (from $\mathrm{SiO}_{2}$ and/or $\mathrm{TiO}_{2}$; inner and outer nanocomposite layers) by a covalent bond. This $\mathrm{C}$-O stretching vibration represented the conjugation of $\mathrm{C}$-dots on the surface of the synthesized $\mathrm{Co}_{\mathrm{x}} \mathrm{Ni}_{1-\mathrm{x}} \mathrm{Fe}_{2} \mathrm{O}_{4} ; \mathrm{x}=0.9 / \mathrm{SiO}_{2} / \mathrm{TiO}_{2}$ nanocomposite ${ }^{84,85}$. Our FTIR results were similar to some recentlypublished research studies ${ }^{86-89}$.

Photocatalytic activity of $\mathrm{Co}_{x} \mathrm{Ni}_{1-x} \mathrm{Fe}_{2} \mathrm{O}_{4 i} \mathrm{x}=0.9 / \mathrm{SiO}_{2} / \mathrm{TiO}_{2} / \mathrm{C}$-dots nanocomposite. The photocatalytic activity of the synthesized C-dots-loaded nanocomposite was evaluated via the photocatalytic degradation of an aqueous solution of chloramine-T trihydrate under UV-light irradiation. Upon increasing the UV-irradiation period, the strong absorption bands of chloramine-T recorded at $225 \mathrm{~nm}$ (the maximum absorbance wavelength $\left(\lambda_{\max }\right)$ for the chloramine-T), reduced continuously, and the removal of chloramine-T solution reached about $80 \%$ after 90 min of UV-light irradiation, as shown in Figs. 8, 9, and 10).

Effect of chloramine-T initial concentration on the degradation efficiency. Degradation efficiency with an irradiation time of chloramine- $\mathrm{T}$ via $10 \mathrm{mg}$ of the prepared nanocomposite in $(50 \mathrm{ml})$ chloramine- $\mathrm{T}$ solution of initial 


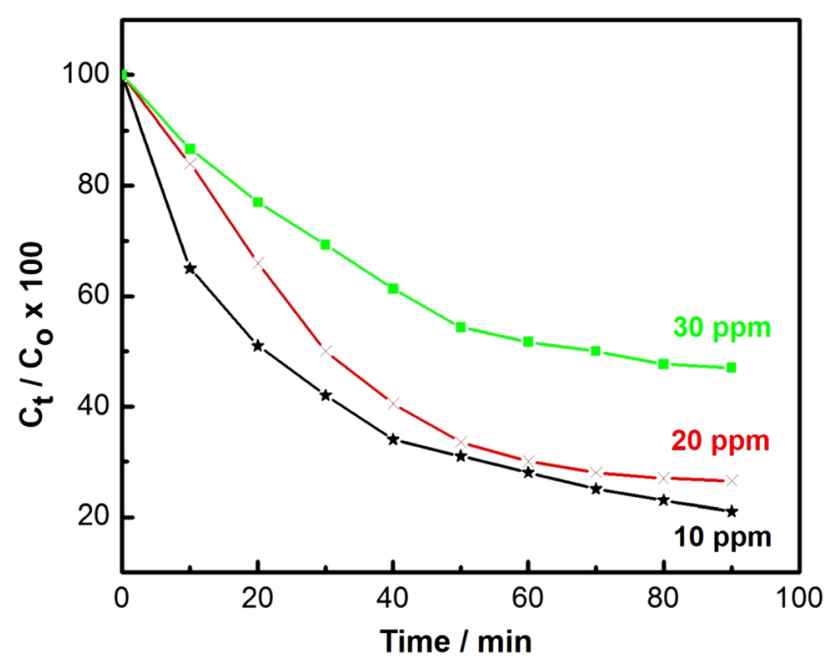

Figure 9. Effect of initial concentration of chloramine-T on the degradation efficiency (10 mg of nanocomposite, $50 \mathrm{ml}$ chloramine-T solution, Temp. $=25^{\circ} \mathrm{C}$ and $\mathrm{pH}=7$ ).

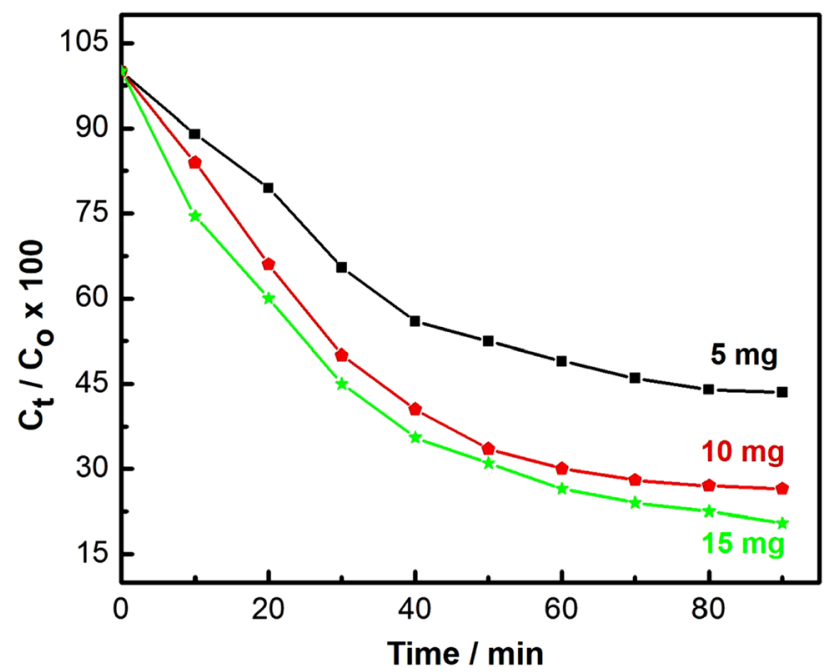

Figure 10. Effect of the photocatalyst dose on the degreadation efficency of chloramine- $\mathrm{T}$ (50 ml chloramine- $\mathrm{T}$ solution $(20 \mathrm{mg} / \mathrm{l})$, Temp. $=25^{\circ} \mathrm{C}$ and $\left.\mathrm{pH} 7\right)$.

concentrations (10, 20 and $30 \mathrm{mg} / \mathrm{l})$ is illustrated in Fig. 9. The color of the solution turned from a turbid white to nearly transparent at the end of the decomposition experiment, with approximately $80 \%$ removal after $90 \mathrm{~min}$ (Figs. 9, 10). Our results showed that the degradation efficiency of chloramine-T is inversely-proportional to its initial concentration. The decomposed percentage of chloramine- $T$ was measured by using $C_{t} / C_{o} \times 100$, where $\mathrm{C}_{\mathrm{t}}$ and $\mathrm{C}_{\mathrm{o}}$ are the remaining and initial concentrations of chloramine-T, respectively.

Effect of the nanocompositedose on degradation efficiency. The influence of a nanocomposite dose on the photodegradation of chloramine-T under UV-light was studied by varying the amount of the prepared photocatalyst between 5 and $20 \mathrm{mg}$ against a fixed concentration of chloramine-T $(20 \mathrm{mg} / \mathrm{l})$, as shown in Fig. 10. The results showed that by increasing the amount of the employed photocatalyst from (5 to $20 \mathrm{mg}$ ), a decrease in the value of $C_{t} / C_{o} \times 100$ was observed from 40 to 20 , respectively. The results also indicated an increase in the degradation efficiency upon increasing the photocatalyst dose from ( 5 to $20 \mathrm{mg}$ ). The observed increase in degradation efficiency with increasing the amount of the photocatalyst in the reaction could be attributed to the increase in the available active area or active sites of the photocatalyst to volume ratio of chloramine-T solution ${ }^{90,91}$.

While Fig. 11 shows a plot of $1 / C_{t}$ against time, which gives a straight-line with intercept equal to $1 / \mathrm{C}_{0}$ and slope $k$. According to the values of $R^{2}>99.5$, the reactions of chloramine-T degradation with the prepared nanocomposite followed pseudo second-order reaction kinetics. Moreover, as indicated in Fig. 12, there is a 


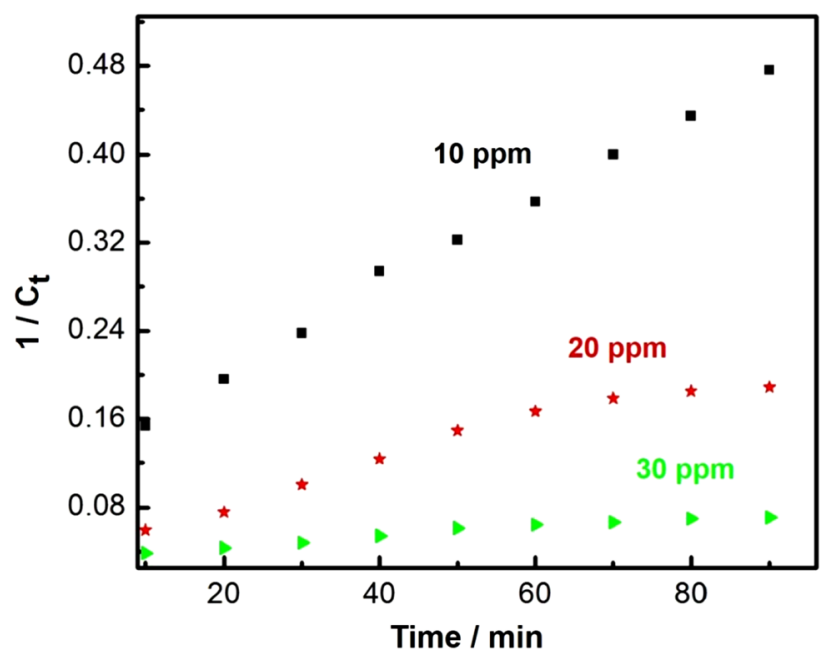

Figure 11. Pseudo second order kinetics of chloramine-T degradation (10 mg of nanocomposite, $50 \mathrm{ml}$ chloramine-T solution, Temp $=25^{\circ} \mathrm{C}$ and $\mathrm{pH} 7$ ).

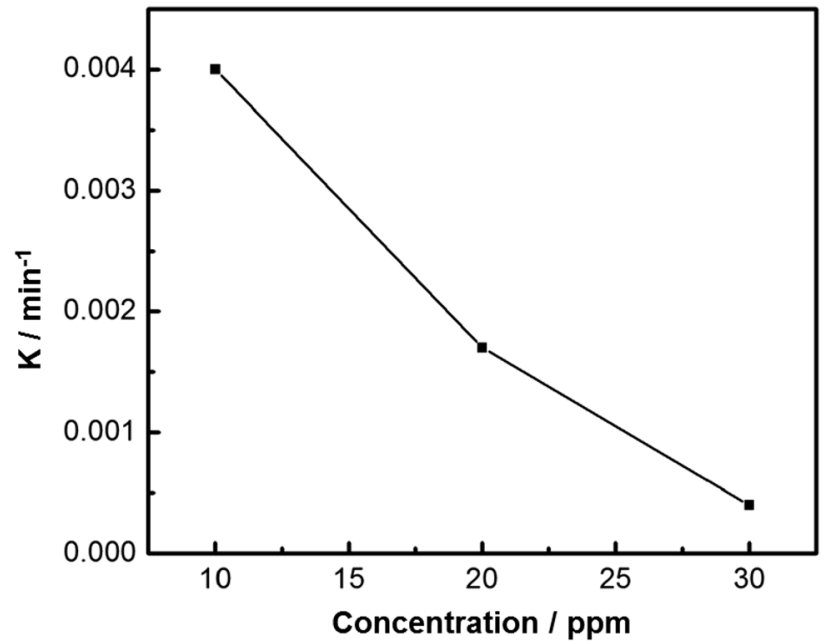

Figure 12. Apparent pseudo second order rate constant vs initial concentration of chloramine-T.

clear inverse dependence of the apparent pseudo second-order rate constant on the initial concentration of chloramine-T.

Effect of $\mathrm{pH}$ value on the photodegradation of chloramine-T. In this part, the role of reaction $\mathrm{pH}$ on the photocatalytic degradation of chloramine- $\mathrm{T}$ was studied in the $\mathrm{pH}$ range from (5 to 9$)$ at room temperature $\left(25 \pm 2{ }^{\circ} \mathrm{C}\right)$. The initial $\mathrm{pH}$ of the chloramine-T solution was set before UV-irradiation and it was not changed during the experiments. The influence of the initial $\mathrm{pH}$ on the photodegradation of chloramine-T under UV-irradiation was investigated, and the results are shown in Fig. 13.

The photodegradation of chloramine- T was enhanced by increasing the $\mathrm{pH}$. It is well known that, the photocatalytic degradation of chloramine- $\mathrm{T}$ is a complicated process, which started with the adsorption on the nanocomposite surface ${ }^{92}$. The photocatalytic performance of the prepared nanocomposite could be attributed to the surface electrical properties, due to the different interlayer anions. The superior surface potential of the nanocomposite facilitated chloramine-T adsorption, which is helpful in promoting the transfer of light-generated charge carriers to the photocatalyst surface ${ }^{93}$.

The initial $\mathrm{pH}$ of the solution is one of the most remarkable parameters controlling the photocatalytic process and can affect the surface charge nature of the photocatalyst and the extent of agglomeration and its stability ${ }^{47,93,94}$. Moreover, $\mathrm{pH}$ manipulates a significant role in the reaction mechanisms that can lead to chloramine-T degradation.

The photodegradation mechanisms affected by varying the $\mathrm{pH}$ values include hydroxyl radical attack, explicit oxidation by the positive holes in the valence band, and explicit reduction by the electrons in the conduction band. In the presence of a photocatalyst, it is assumed that photocatalytic degradation is likely to happen due 


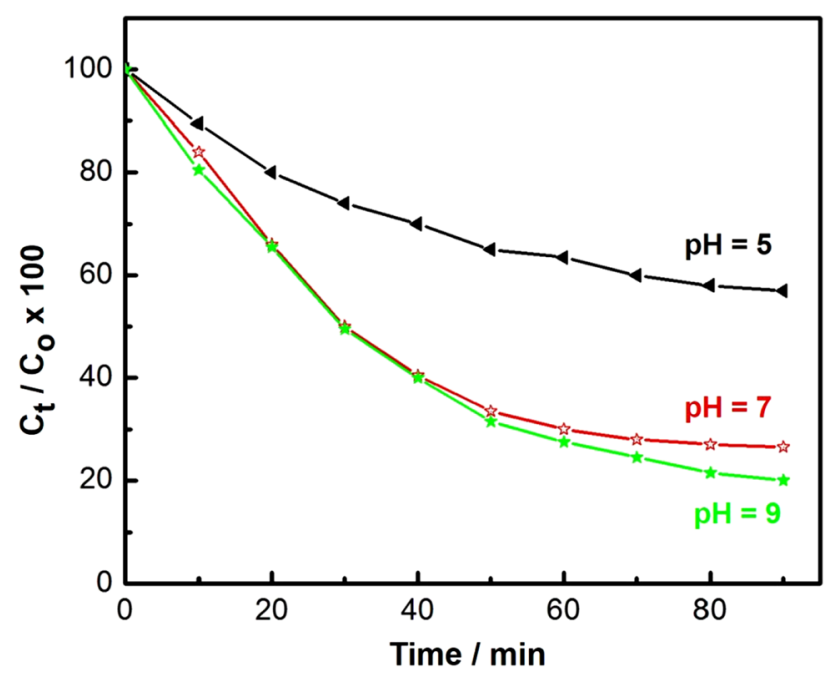

Figure 13. Effect of $\mathrm{pH}$ on the degradation of chloramine- $\mathrm{T}$ (10 $\mathrm{mg}$ nanocomposite, $50 \mathrm{ml}$ chloramine- $\mathrm{T}$ (20 $\mathrm{mg} / \mathrm{l})$ and $100 \mathrm{~min}$ UV-irradiation).

to the formation of electron-hole pairs on the exterior of the employed photocatalyst, due to UV-irradiation. Oxidative potential of holes either reacts with the-OH groups to form hydroxyl radicals or oxidizes the reactive chloramine- $\mathrm{T}$ to form a degradation product ${ }^{95}$. The reactions of chloramine-T and the employed photocatalyst can be summarized as follows (Eqs. 3-6).

$$
\begin{gathered}
\mathrm{C}-\text { dots loaded composite }+\mathrm{h} v \rightarrow \text { nanocomposite }\left(\mathrm{e}_{\mathrm{CB}}^{-}+\mathrm{h}_{\mathrm{VB}}^{+}\right) \\
\mathrm{h}_{\mathrm{VB}}^{+}+\text {Chloramine }-\mathrm{T} \rightarrow \text { Chloramine }-\mathrm{T}^{\cdot+} \text { (Oxidation of the compound) }
\end{gathered}
$$

Or

$$
\begin{gathered}
\mathrm{h}_{\mathrm{VB}}^{+}+\mathrm{OH}^{-} \rightarrow \mathrm{OH}^{\cdot} \\
\mathrm{OH}^{\cdot}+\text { chloramine }-\mathrm{T} \rightarrow(\text { Degredation product })
\end{gathered}
$$

Interestingly, the concentration of $\mathrm{OH}^{\cdot}$ radicals is relatively-higher at higher $\mathrm{pH}$ values (alkaline medium), and this may also be another reason for the increase in photodegradation of strong alkaline media. In addition, the high $\mathrm{pH}$ value (in alkaline media) is beneficial to the formation of $\mathrm{OH}^{\cdot}$ radicals during the reaction between dissolved oxygen and excited state electrons, which makes the degradation of chloramine-T noteworthy ${ }^{96}$, while, at low $\mathrm{pH}$ values, a decrease in photodegradation efficiency is noticed that may be attributed to the instability of the prepared nanocomposite through a cathodic dislocation of the valence band position, which gives rise to a weakening of the oxidation capability of the holes. In conclusion, the initial reaction $\mathrm{pH}$ has an influence on the surface charge of the catalyst and the adsorption characteristics of ions $s^{47,95}$.

The proposed mechanism of interaction between the prepared nanocomposite and chloramine- $\mathrm{T}$ is shown in Fig. 14. Upon UV-light excitation of $\mathrm{TiO}_{2}$ layer, charge carriers will be photogenerated and redox reactions will be initiated. Then, the generated free radicals (such as $\mathrm{OH} \cdot \mathrm{And}_{2}{ }^{-{ }^{-}}$) will degrade chloramine-T into two potential products, p-touluene sulfonamide and hypochlorites that can be easily dissociated into $\mathrm{O}_{2}$ and $\mathrm{Cl}^{-}$ions. Since, there are no published reports about the degradation of chloramine-T till the moment, more investigations via high-performance liquid chromatography (HPLC) and gas chromatography-mass spectrometry (GC-MS) are required to analyze with more details the degradation products of chloramine-T.

In vitro antimicrobial activity of the synthesized $\mathrm{Co}_{x} \mathrm{Ni}_{1-\mathrm{x}} \mathrm{Fe}_{2} \mathrm{O}_{4} ; \mathrm{x}=0.9 / \mathrm{SiO}_{2} / \mathrm{TiO}_{2} / \mathrm{C}$-dots nanocomposite. Agar diffusion technique was used to test the antimicrobial potential of the prepared nanocomposite (screening procedure). C-dots-loaded nanocomposite $(15 \mu \mathrm{g} / \mathrm{ml})$ showed comparatively-higher antimicrobial potential against all examined bacteria and Candida species compared with C-dots. Screening data verified that the fabricated nanocomposite possessed predominant antibacterial efficacy against E. coli ( $36 \mathrm{~mm}$ ZOI, Fig. 15a), P. aeruginosa (33 mm ZOI) and B. cereus (24 mm ZOI, Fig. 15b) as seen in Table 1. Interestingly, the synthesized C-dots loaded nanocomposite exhibited more effective antimicrobial capacities than bare C-dots and other conventional antimicrobial agents (AMC).

Our previously-prepared $\mathrm{Co}_{\mathrm{x}} \mathrm{Ni}_{1-\mathrm{x}} \mathrm{Fe}_{2} \mathrm{O}_{4} \mathrm{X}=0.9 / \mathrm{SiO}_{2} / \mathrm{TiO}_{2}$; nanocomposite ${ }^{47}$ exhibited antibacterial action of (16 mm, ZOI) against $E$. coli and an antifungal potential against C. albicans of $(10 \mathrm{~mm}, \mathrm{ZOI})$. Interestingly, by making a comparison, we observed an enhanced antibacterial activity of C-dots-loaded nanocomposite 


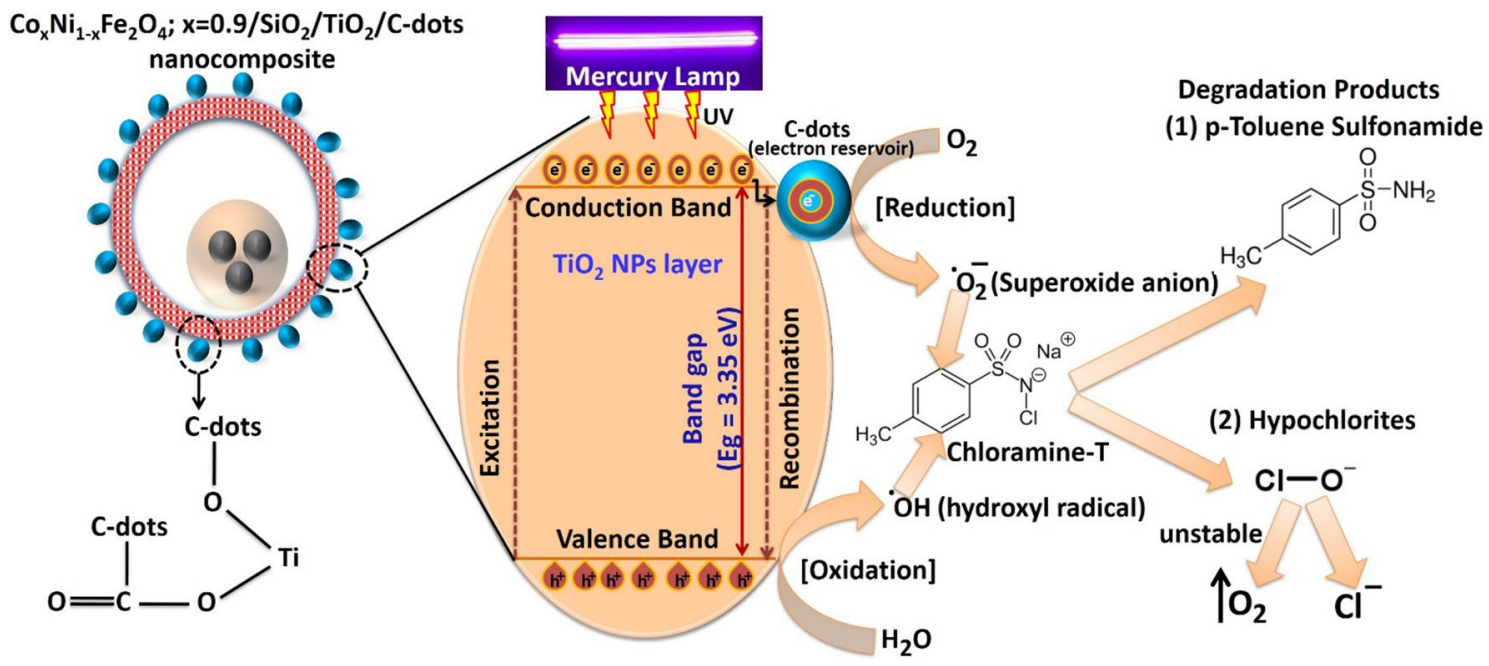

Figure 14. Proposed mechanism of photocatalytic degradation of chloramine-T with the prepared nanocomposite.

(Fig. 15, Table 1) suggesting the possibility of synergistic potential between $\mathrm{Co}_{\mathrm{x}} \mathrm{Ni}_{1-\mathrm{x}} \mathrm{Fe}_{2} \mathrm{O}_{4} / \mathrm{SiO}_{2} / \mathrm{TiO}_{2} ; \mathrm{x}=0.9$ nanocomposite and C-dots.

It was also noted that the prepared nanocomposites were more effective against Gram-negative than Grampositive bacteria. One possible cause is in how the bacterial cell walls are constructed, as cell walls of Gramnegative species consist primarily of films (thin layers) of peptidoglycans, lipopolysaccharides, and lipids, while, cell walls of Gram-positive species have thick arrangements of peptidoglycans ${ }^{97}$.

The prepared C-dots-loaded nanocomposite can be used as a powerful antifungal agent, as it possesses an extraordinary antifungal potency against C. tropicalis (35 mm ZOI, Fig. 15c) and C. albicans (28 mm ZOI) as presented in Table 1.

The MIC values of bare C-dots and C-dots-loaded nanocomposite against all tested pathogenic bacteria and Candida sp. were in the range of 6.25 to $0.024 \mu \mathrm{g} / \mathrm{ml}$, as shown in Table 1 . The synthesized nanocomposite possessed MIC values of about $0.024 \mu \mathrm{g} / \mathrm{ml}$ against E. coli, $0.097 \mu \mathrm{g} / \mathrm{ml}$ against C. tropicalis, and $0.390 \mu \mathrm{g} / \mathrm{ml}$ against $B$. cereus.

Surprisingly, by comparing these results with those in our previously-published paper ${ }^{47}$, the synthesized $\mathrm{Co}_{\mathrm{x}} \mathrm{Ni}_{1-\mathrm{x}} \mathrm{Fe}_{2} \mathrm{O}_{4} ; \mathrm{x}=0.9 / \mathrm{SiO}_{2} / \mathrm{TiO}_{2}$ nanocomposite possessed $\mathrm{MIC}$ values of $(3.12 \mu \mathrm{g} / \mathrm{ml})$ against E. coli and $(12.5 \mu \mathrm{g} / \mathrm{ml})$ against C. albicans. However, the newly-prepared C-dots loaded nanocomposite showed more promising MIC results, of about $(0.024 \mu \mathrm{g} / \mathrm{ml}$ against $E$. coli $)$ and $(0.781 \mu \mathrm{g} / \mathrm{ml} \mathrm{ZOI} \mathrm{against} \mathrm{C.} \mathrm{albicans),} \mathrm{sug-}$ gesting it had good antimicrobial abilities at very low concentrations.

Interestingly, there is a correlation between the physical characteristics (surface area) of the prepared nanocomposite and its recorded antimicrobial capabilities. The measured surface area of the C-dots-loaded nanocomposite was $\left(28.29 \pm 0.19 \mathrm{~m}^{2} / \mathrm{g}\right)$ with a unimodal and narrow pore size distribution, with an average pore diameter of $(13.3 \mathrm{~nm})$ and an average pore volume of $\left(0.001253 \mathrm{~cm}^{3} / \mathrm{g}\right)$. The prepared nanocomposite possessed two classes of pores in its outer shell $\left(\mathrm{TiO}_{2} \mathrm{NPs}\right)$, mesoporous and macropores ${ }^{98}$. This surface area and pore size distribution expanded its connection areas (active sites) to absorb more microbial cells (diameter of $E$. coli is $0.25 \mu \mathrm{m}$ ). These physical features were significant in enhancing its antimicrobial potency at a low concentration $(0.024 \mu \mathrm{g} / \mathrm{ml})$ against all tested pathogenic bacteria and Candida species.

Effect of UV-irradiation on the antimicrobial potential of $\mathrm{Co}_{x} \mathrm{Ni}_{1-x} \mathrm{Fe}_{2} \mathrm{O}_{4} ; \mathrm{x}=0.9 / \mathrm{SiO}_{2} / \mathrm{TiO}_{2}$ /C-dots nanocomposite in liquid media. Comparative study of the repression percentage of $E$. coli, $B$. cereus, and C. tropicalis by non-irradiated and UV-irradiated nanocomposite was conducted and is shown in Fig. 16.

The restraint percentage of the examined pathogens due to nanocomposite treatment decreased as a function of time, suggesting that it maintained effective antimicrobial capabilities against the colonies of E. coli, B. cereus, and C. tropicalis. as shown in Fig. 16a-c.

Interestingly, the UV-irradiated nanocomposite showed higher antimicrobial potential compared with the non-irradiated, as shown in Fig. 16.

The highest recorded hindrance percentages of non-irradiated and UV-irradiated nanocomposites against E. coli were $34.12 \%$ and $80.47 \%$, respectively. Inhibition percentages were $22.56 \%$ and $49.54 \%$ for B. cereus and $50.45 \%$ and $78.54 \%$ for C. tropicalis after 60 min of UV-irradiation (practice time) as shown by non-irradiated and UV-irradiated nanocomposites, respectively.

The effect of UV-irradiation on the nanocomposite can be explained by the photo-created reactive oxygen species (ROS), which can disintegrate bacterial cells. The observed antimicrobial capabilities were also due to the effective UV-absorption by the synthesized nanocomposite. $\mathrm{OH}$ radicals can be also produced by irradiating the nanocomposite with UV. Due to the electron shift within the microbial cells and the nanocomposite, $\mathrm{OH}$ radicals can damage bacterial cells by reducing co-enzyme contents ${ }^{99}$. 

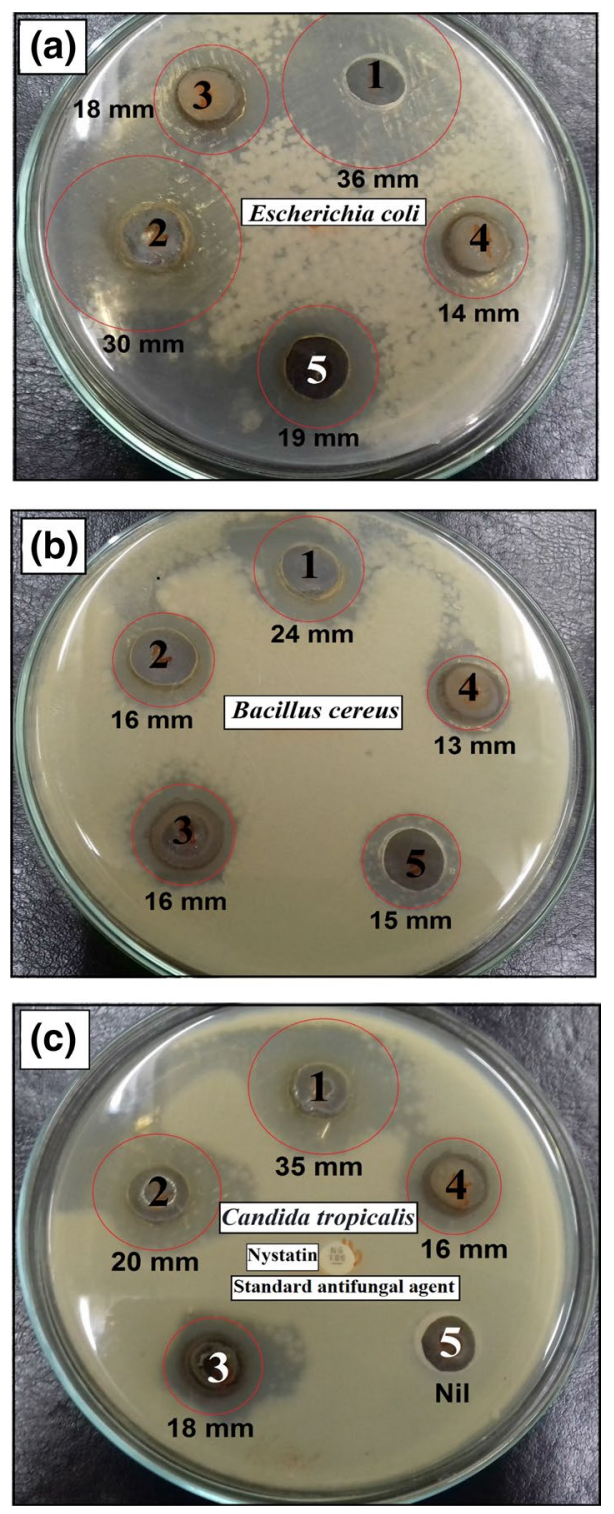

Figure 15. Antibacterial and antifungal activities of bare $\mathrm{C}$-dots and $\mathrm{Co}_{\mathrm{x}} \mathrm{Ni}_{1-\mathrm{x}} \mathrm{Fe}_{2} \mathrm{O}_{4} ; \mathrm{x}=0.9 / \mathrm{SiO}_{2} / \mathrm{TiO}_{2} / \mathrm{C}$-dots nanocomposite on: (a) Escherichia coli, (b) Bacillus cereus and (c) Candida tropicalis measured as ZOI ( $\mathrm{mm}$ ). $1=\mathrm{Co}_{\mathrm{x}} \mathrm{Ni}_{1-\mathrm{x}} \mathrm{Fe}_{2} \mathrm{O}_{4} ; \mathrm{x}=0.9 / \mathrm{SiO}_{2} / \mathrm{TiO}_{2} / \mathrm{C}$-dots nanocomposite $(15 \mu \mathrm{g} / \mathrm{ml}), 2=\mathrm{Co}_{\mathrm{x}} \mathrm{Ni}_{1-\mathrm{x}} \mathrm{Fe}_{2} \mathrm{O}_{4} ; \mathrm{x}=0.9 / \mathrm{SiO}_{2} / \mathrm{TiO}_{2} / \mathrm{C}$ dots nanocomposite $(10 \mu \mathrm{g} / \mathrm{ml}), 3=$ bare C-dots $(15 \mu \mathrm{g} / \mathrm{ml}), 4=$ bare C-dots $(10 \mu \mathrm{g} / \mathrm{ml})$ and $5=$ Amoxicillin/ Clavulanic Acid $(100 \mu \mathrm{g} / \mathrm{ml}$, standard antibacterial agent).

In addition, metal oxides (MOs), like $\mathrm{TiO}_{2}$ (the composite's external layer), possess positive charges in slightlyacidic media, while microbes have negative charges. This creates an electromagnetic attraction between microbes and MOs, resulting in microbial cell oxidization and consequent damage ${ }^{100}$. Moreover, nanomaterials can damage cellular proteins and DNA by binding with electron-donating constructions such as thiols, carbohydrates, indoles, hydroxyls, and amides. Additionally, they can induce cracks in the cell walls of bacteria, causing extensive permeability and cell death ${ }^{101}$. We previously-reported that our $\mathrm{Co}_{\mathrm{x}} \mathrm{Ni}_{1-\mathrm{x}} \mathrm{Fe}_{2} \mathrm{O}_{4} ; \mathrm{x}=0.9 / \mathrm{SiO}_{2} / \mathrm{TiO}_{2}$ nanocomposite had a negative charge in neutral media, but tested microbes media is slightly-acidic $(\mathrm{pH}=6)$, which can change the outside charge of the nanocomposite to positive, which is in a good agreement with our recorded results.

Further, our previous $\mathrm{Co}_{\mathrm{x}} \mathrm{Ni}_{1-\mathrm{x}} \mathrm{Fe}_{2} \mathrm{O}_{4} ; \mathrm{x}=0.9 / \mathrm{SiO}_{2} / \mathrm{TiO}_{2}$ nanocomposite ${ }^{47}$ displayed an inhibition \% against E. coli of about $70.45 \%$ after UV-activation, while the newly-synthesized $\mathrm{Co}_{\mathrm{x}} \mathrm{Ni}_{1-\mathrm{x}} \mathrm{Fe}_{2} \mathrm{O}_{4} ; \mathrm{x}=0.9 / \mathrm{SiO}_{2} / \mathrm{TiO}_{2} /$ C-dots nanocomposite showed an inhibition \% of $80.47 \%$ (Fig. 16a). In addition, its repression to Candida species reached (78.54\%; Fig. 16c) compared with only 50.85\% for the previous $\mathrm{Co}_{\mathrm{x}} \mathrm{Ni}_{1-\mathrm{x}} \mathrm{Fe}_{2} \mathrm{O}_{4} ; \mathrm{x}=0.9 / \mathrm{SiO}_{2} / \mathrm{TiO}_{2}$ nanocomposite $e^{47}$.

Antibiofilm potential of $\mathrm{Co}_{x} \mathrm{Ni}_{1-x} \mathrm{Fe}_{2} \mathrm{O}_{4} ; \mathrm{x}=0.9 / \mathrm{SiO}_{2} / \mathrm{TiO}_{2} / \mathrm{C}$-dots nanocomposite. Biofilm formation is popular in various exopolysaccharide-producing pathogenic microorganisms ${ }^{59,102}$. Biofilms are 


\begin{tabular}{|c|c|c|c|c|c|c|c|}
\hline Pathogenic microbes & $\begin{array}{l}\text { ZOI of bare c-dots } \\
(10 \mu \mathrm{g} / \mathrm{ml})(\mathrm{mm})\end{array}$ & $\begin{array}{l}\text { ZOI of bare c-dots } \\
(15 \mu \mathrm{g} / \mathrm{ml})(\mathrm{mm})\end{array}$ & $\begin{array}{l}\text { MIC of bare c-dots } \\
(\mu \mathrm{g} / \mathrm{ml})\end{array}$ & $\begin{array}{l}\text { ZOI of } \\
\mathrm{CoxNi}{ }_{1-x} \mathrm{Fe}_{2} \mathrm{O}_{4} ; \\
\mathrm{x}=0.9 / \mathrm{SiO}_{2} / \mathrm{TiO}_{2} / \mathrm{C}- \\
\text { dots }(10 \mu \mathrm{g} / \mathrm{ml}) \\
(\mathrm{mm})\end{array}$ & $\begin{array}{l}\text { ZOI of } \\
\mathrm{CoxNi}_{1-\mathrm{x}} \mathrm{Fe}_{2} \mathrm{O}_{4} ; \\
\mathrm{x}=0.9 / \mathrm{SiO}_{2} / \mathrm{TiO}_{2} / \mathrm{C}- \\
\operatorname{dots}(15 \mu \mathrm{g} / \mathrm{ml}) \\
(\mathrm{mm})\end{array}$ & $\begin{array}{l}\text { MIC of } \\
\mathrm{CoxNi}_{1-\mathrm{x}} \mathrm{Fe}_{2} \mathrm{O}_{4} ; \\
\mathrm{x}=0.9 / \mathrm{SiO}_{2} / \mathrm{TiO}_{2} / \mathrm{C}- \\
\operatorname{dots}(\mu \mathrm{g} / \mathrm{ml})\end{array}$ & AMC or NS \\
\hline Escherichia coli & $14^{\mathrm{d}} \pm 0.2516$ & $18^{\mathrm{d}} \pm 0.2516$ & 1.562 & $30^{\mathrm{e}} \pm 0.1000$ & $36^{\mathrm{g}} \pm 0.2516$ & 0.024 & $19^{c} \pm 0.2516$ \\
\hline $\begin{array}{l}\text { Pseudomonas aer- } \\
\text { uginosa }\end{array}$ & $13^{c} \pm 0.2081$ & $14^{\mathrm{b}} \pm 0.1154$ & 1.562 & $21^{\mathrm{d}} \pm 0.3000$ & $33^{\mathrm{e}} \pm 0.4725$ & 0.195 & $10^{\mathrm{a}} \pm 0.1527$ \\
\hline $\begin{array}{l}\text { Staphylococcus aureus; } \\
\text { MRSA }\end{array}$ & $9^{\mathrm{a}} \pm 0.4041$ & $10^{\mathrm{a}} \pm 0.5291$ & 12.5 & $11^{\mathrm{a}} \pm 0.2309$ & $12^{\mathrm{a}} \pm 0.4725$ & 6.25 & Nil \\
\hline Bacillus cereus & $13^{\mathrm{c}} \pm 0.4509$ & $16^{c} \pm 0.1000$ & 0.751 & $16^{\mathrm{b}} \pm 0.4506$ & $24^{\mathrm{c}} \pm 0.1154$ & 0.390 & $15^{\mathrm{b}} \pm 0.3214$ \\
\hline Klebsiella pneumoniae & $9^{\mathrm{a}} \pm 0.4509$ & $10^{\mathrm{a}} \pm 0.2516$ & 6.25 & $16^{\mathrm{b}} \pm 0.4041$ & $18^{\mathrm{b}} \pm 0.1154$ & 3.125 & Nil \\
\hline Candida albicans & $12^{\mathrm{b}} \pm 0.4041$ & $16^{c} \pm 0.2516$ & 3.125 & $16^{\mathrm{b}} \pm 0.1732$ & $25^{\mathrm{d}} \pm 0.2000$ & 0.781 & Nil \\
\hline Candida tropicalis & $16^{\mathrm{e}} \pm 0.3214$ & $18^{\mathrm{e}} \pm 0.2516$ & 0.781 & $20^{c} \pm 0.3000$ & $35^{\mathrm{f}} \pm 0.3055$ & 0.097 & Nil \\
\hline LSD & 0.76667 & 1.50000 & - & 4.03333 & 0.96667 & - & - \\
\hline
\end{tabular}

Table 1. Antimicrobial activities of bare C-dots and $\mathrm{Co}_{\mathrm{x}} \mathrm{Ni}_{1-\mathrm{x}} \mathrm{Fe}_{2} \mathrm{O}_{4} ; \mathrm{x}=0.9 / \mathrm{SiO}_{2} / \mathrm{TiO}_{2} / \mathrm{C}$-dots nanocomposite, against multi-drug-resistant (MDR) bacteria and pathogenic Candida species, measured as ZOI ( $\mathrm{mm}$ ) and MIC $(\mu \mathrm{g} / \mathrm{ml})$. Values are presented as means \pm SD $(n=3)$. Data within the groups were analyzed using one-way analysis of variance (ANOVA) followed by superscript letters (a-g) Duncan's multiple range test (DMRT), LSD least significant difference. Nil means that no ZOI was measured. AMC amoxicillin/clavulanic acid (standard antibacterial agent). NS Nystatin (standard antifungal agent).

formed by the tested pathogenic bacteria and yeast with and without nanocomposite treatment was evaluated by using test tubes process ${ }^{103}$.

Figure 17a displays the antibiofilm ability of the prepared nanocomposite against E. coli. E. coli grew without our nanocomposite and shows a clear whitish-yellow matt in the air-liquid interface of the tubes. This matt was completely-connected to the inner wall of the tubes and resembled a blue circle after CV staining. A blue solution was also formed after dissolving the CV-stained circle by absolute ethanol, as shown in Fig. 17a.

On the other hand, the restriction of bacterial rings growth was observed in $E$. coli inoculated with tested nanocomposite $(15 \mu \mathrm{g} / \mathrm{ml})$, and the blue color corresponding to CV-stained bacterial cells was faint, as shownin Fig. 16A. Similar results were observed for B. cereus and C. trobicalis biofilm suppression, as shown in Figs. 17b,c respectively.

To determine the restraint percentage of bacterial and yeast biofilm, a UV-Vis. spectrophotometer was used (at $570 \mathrm{~nm}$ ). The optical density (O.D.) was measured after separating the CV-stained bacterial and yeast biofilms through ethanol. Table 2 presents the reduction percentage of the biofilms created by the examined bacteria and yeast strains. The highest suppression percentage was recorded against E. coli (93.92\%, Fig. 17a), followed by $C$. trobicalis $(92.35 \%$, Fig. $17 \mathrm{c})$ and C. albicans $(66.29 \%$, Table 2$)$ after inoculation with $(10 \mu \mathrm{g} / \mathrm{ml})$ of the prepared nanocomposite.

In addition, the newly-synthesized $\mathrm{Co}_{\mathrm{x}} \mathrm{Ni}_{1-\mathrm{x}} \mathrm{Fe}_{2} \mathrm{O}_{4} ; \mathrm{x}=0.9 / \mathrm{SiO}_{2} / \mathrm{TiO}_{2} / \mathrm{C}$-dots nanocomposite was more active against biofilm creation than the previously-synthesized $\mathrm{Co}_{\mathrm{x}} \mathrm{Ni}_{1-\mathrm{x}} \mathrm{Fe}_{2} \mathrm{O}_{4} ; \mathrm{x}=0.9 / \mathrm{SiO}_{2} / \mathrm{TiO}_{2}$ nanocomposite ${ }^{47}$. It exhibited an inhibition against biofilm-producing E. coli of (93.92\%, Table 2), compared with (92.82\%) for the $\mathrm{Co}_{\mathrm{x}} \mathrm{Ni}_{1-\mathrm{x}} \mathrm{Fe}_{2} \mathrm{O}_{4} ; \mathrm{x}=0.9 / \mathrm{SiO}_{2} / \mathrm{TiO}_{2}$ nanocomposite. Moreover, it inhibited biofilm production by $C$. trobicalis (92.35\%, Table 2) compared with only (77.84\%) by the $\mathrm{Co}_{\mathrm{x}} \mathrm{Ni}_{1-\mathrm{x}} \mathrm{Fe}_{2} \mathrm{O}_{4} ; \mathrm{x}=0.9 / \mathrm{SiO}_{2} / \mathrm{TiO}_{2}$ nanocomposite.

The prepared nanocomposite was used to control the biofilm growth at its adhesion level (known as the initial level $)^{104}$. The change in the inhibitory percentage can be assigned to different factors such as antimicrobial potential, biosorption (due to the large exterior surface area of the nanocomposite), physical properties (size of particles and porosity), attack abilities, and many chemical characteristics managing the interaction of the synthesized nanocomposite and biofilms ${ }^{103,105}$.

It was also observed that the prepared nanocomposite significantly-repressed $E$. coli by more than $98 \%$ with $0.024 \mu \mathrm{g} / \mathrm{ml}$ (MIC, Table 1). When the exopolysaccharide construction is inhibited (the essential fragments for biofilm expansion), E.coli cannot create its biofilm ${ }^{59,103}$.

To clarify the antibiofilm capabilities of the nanocomposite, we attempted an activity mechanism against $E$. coli and $C$. tropicalis biofilms using SEM/EDX analysis ${ }^{48,106}$. SEM images revealed the shape of bacterial and yeast cells before and after nanocomposite treatment.

In the control sample (non-treated bacterial and yeast cells), bacterial and yeast colonies were regularly-grown and exhibited normal cellular shapes with healthy cell surface and concentrated biofilm, as shown in Fig. 18a,b.

After nanocomposite treatment, observable morphological changes were recognized in E. coli and C. tropicalis cells (Fig. 18c, and d). In addition, an observable lysis of external surface was accompanied by deformations and reductions in the viable number of E. coli and C. tropicalis cells. Furthermore, biofilm development was inhibited. EDX elemental analysis revealed the presence of Ti and Si atoms (atoms of nanocomposite's outer shells) and $\mathrm{C}$ atoms for $\mathrm{C}$-dots at deformation areas and at the outer surface of the treated E. coli and C. tropicalis cells, confirming the action of the tested nanocomposite, as shown in Fig. 18e, and $\mathrm{f}$.

One possible reason for the powerful activity against the cells of E. coli and C. tropicalis could be the large surface area $\left(28.29 \mathrm{~m}^{2} / \mathrm{g}\right)$, which allows for a conventional immobile connection between the negatively-charged bacterial cell walls and the nanocomposite, as shown in Fig. 18c, and $\mathrm{d}^{107,108}$. 

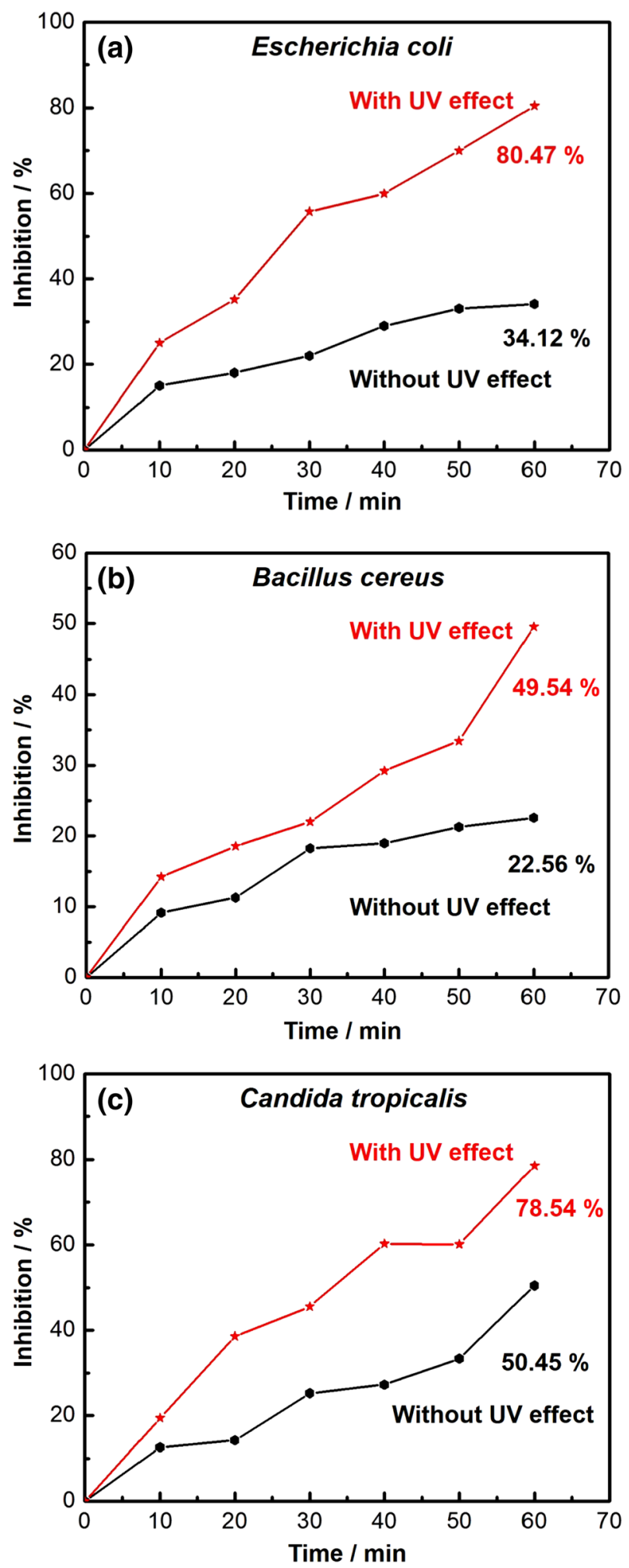

Figure 16. Antimicrobial activity of UV-irradiated $\mathrm{Co}_{\mathrm{x}} \mathrm{Ni}_{1-\mathrm{x}} \mathrm{Fe}_{2} \mathrm{O}_{4} ; \mathrm{x}=0.9 / \mathrm{SiO}_{2} / \mathrm{TiO}_{2} / \mathrm{C}$-dots nanocomposite against different pathogenic microbes: (a) Escherichia coli, (b) Bacillus cereus and (c) Candida tropicalis.

This result is in a good agreement with various published reports on the interaction between MO NPs and pathogenic microorganisms by electrostatic potential, resulting in bacterial membrane detachment ${ }^{107,109,110}$. 

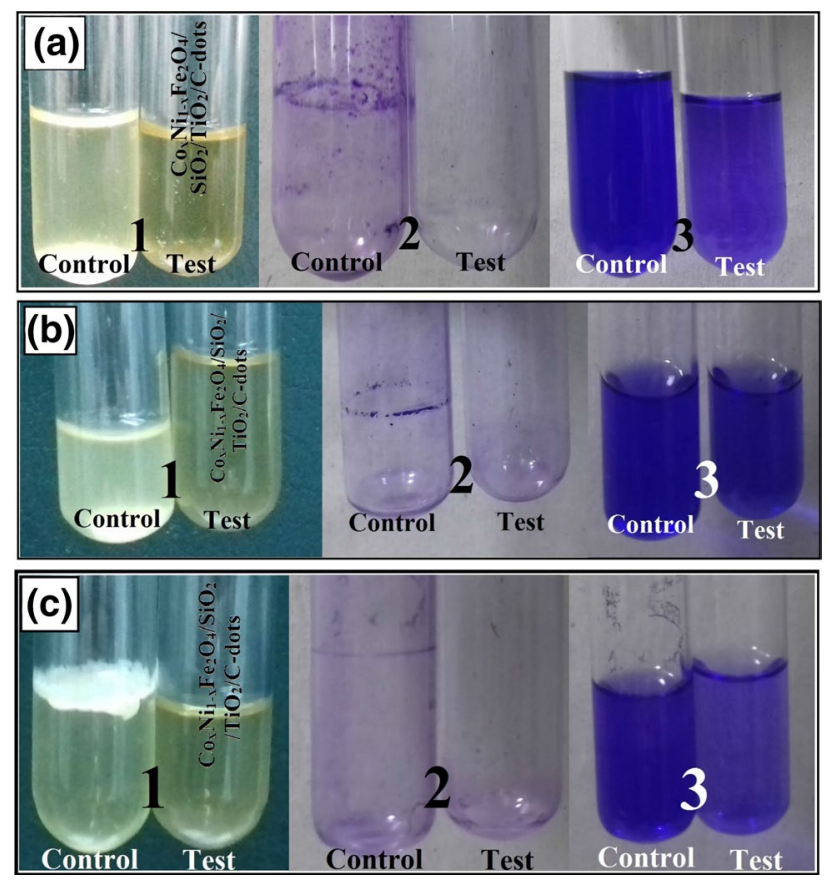

Figure 17. Antibiofilm activity of $\mathrm{Co}_{\mathrm{x}} \mathrm{Ni}_{1-\mathrm{x}} \mathrm{Fe}_{2} \mathrm{O}_{4} ; \mathrm{x}=0.9 / \mathrm{SiO}_{2} / \mathrm{TiO}_{2} / \mathrm{C}$-dots nanocomposite. $(15 \mu \mathrm{g} / \mathrm{ml})$ using tube method against (a) Escherichia coli, (b) Bacillus cereus and (c) Candida tropicalis, showing (1) Growth of the bacterial and yeast cells and biofilm formation (rings) without nanocomposite treatment and the inhibition of bacterial and yeast growth after treatment, (2) Staining of the adherent bacterial and yeast cells with crystal violet and (3) Removal and dissolution of the adherent bacterial and yeast cells by ethanol for semi-quantitative biofilm inhibition determination (as shown in Table 2).

\begin{tabular}{|c|c|c|c|}
\hline Bacterial and yeast strains & O.D. of crystal violet stain at $570 \mathrm{~nm}$ (control) & $\begin{array}{l}\text { O.D. of crystal violet stain at } 570 \mathrm{~nm} \text { (treated with } \mathrm{Co}_{\mathrm{x}} \mathrm{Ni}_{1-\mathrm{x}} \mathrm{Fe}_{2} \mathrm{O}_{4} ; \mathrm{x}=0.9 / \\
\mathrm{SiO}_{2} / \mathrm{TiO}_{2} / \mathrm{C} \text {-dots nanocomposite) }\end{array}$ & Inhibition \% \\
\hline Escherichia coli & $3.981^{\mathrm{g}} \pm 0.0206$ & $0.242^{\mathrm{a}} \pm 0.0216$ & 93.92 \\
\hline Pseudomonas aeruginosa & $1.254^{\mathrm{b}} \pm 0.0096$ & $0.615^{\mathrm{c}} \pm 0.0035$ & 50.35 \\
\hline Staphylococcus aureus; MRSA & $1.060^{\mathrm{a}} \pm 0.0055$ & $0.564^{\mathrm{b}} \pm 0.0020$ & 48.49 \\
\hline Bacillus cereus & $1.735^{\mathrm{c}} \pm 0.0291$ & $0.606^{c} \pm 0.0025$ & 65.07 \\
\hline Klebsiella pneumoniae & $2.170^{\mathrm{d}} \pm 0.0026$ & $1.025^{\mathrm{e}} \pm 0.0020$ & 52.76 \\
\hline Candida albicans & $2.225^{\mathrm{e}} \pm 0.0343$ & $0.750^{\mathrm{d}} \pm 0.0049$ & 66.29 \\
\hline Candida tropicalis & $2.904^{\mathrm{f}} \pm 0.0475$ & $0.222^{\mathrm{a}} \pm 0.0049$ & 92.35 \\
\hline LSD & 0.07633 & 0.04300 & - \\
\hline
\end{tabular}

Table 2. Semi-quantitative inhibition of the biofilm formation by non-treated and nanocomposite-treated bacterial and yeast pathogens. Values are presented as means $\pm S D(n=3)$. Data within the groups were analyzed using one-way analysis of variance (ANOVA) followed by superscript letters (a-g) Duncan's multiple range test (DMRT), LSD least significant difference.

A recent study reported that MO NPs could induce oxidative stress in pathogenic microbes ${ }^{111}$, and quicklydamage their cell membranes upon exposure to increased cellular ROS levels. In this study, the prepared nanocomposite was externally-linked to E. coli and C. tropicalis cells through electrostatic attraction and reduced the bacterial and yeast cell numbers via membrane leakages ${ }^{109}$. Our suggested action mechanism started with the adhesion of the nanocomposite to the exterior surface of $E$. coli and C. tropicalis. Then, $\mathrm{Ti}^{2+}, \mathrm{Si}^{2+}$ ions (from the external shell) and $\mathrm{Fe}^{+2}$ (from the core) penetrated the tested bacterial and yeast cells and destroyed their biological molecules, such as microbial mitochondria and DNA. After that, cellular toxicity due to oxidative tension and the generated ROS had been increased.

\section{Conclusion}

$\mathrm{Co}_{\mathrm{x}} \mathrm{Ni}_{1-\mathrm{x}} \mathrm{Fe}_{2} \mathrm{O}_{4} ; \mathrm{x}=0.9 / \mathrm{SiO}_{2} / \mathrm{TiO}_{2}$ nanocomposite was prepared using a layer-by-layer approach. It was then decorated with $\mathrm{C}$-dots synthesized using a one-pot hydrothermal method. The prepared nanocomposite was examined using several instruments to understand its phase, crystallinity, UV-absorption, band gap energy, 

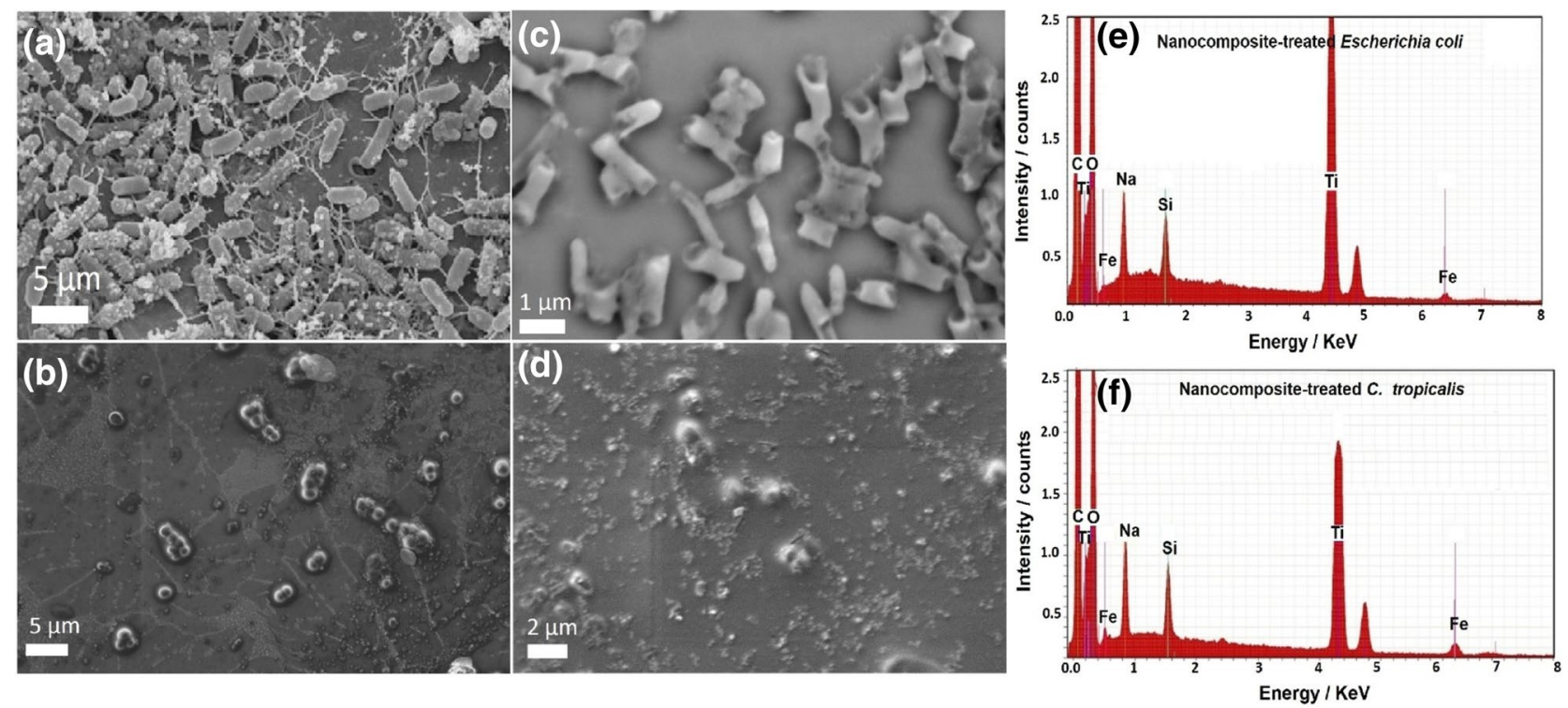

Figure 18. SEM and corresponding EDX elemental analysis of Escherichia coli and Candida trobicalis: (a) Normal bacterial cells (E. coli) without nanocomposite treatment, (b) Normal yeast cells (C. tropicalis) without nanocomposite treatment, (c) Depressed and deformed bacterial cell after nanocomposite treatment, (d) Depressed and deformed Candida cell by nanocomposite treatment showing the complete lysis of Candida cell and loss of budding formation, (e) Corresponding EDX elemental analysis of the treated $E$. coli cell confirming the cellular internalization of the prepared nanocomposite in E. coli cells, and (f) Corresponding EDX elemental analysis of the treated $C$. tropicalis cell confirming the cellular internalization of the synthesized nanocomposite in C. tropicalis cells.

surface area, pore size distribution, average size of particle, morphology and purity. The prepared nanocomposite was designed for wastewater treatment. Thus, two different applications were carried out: photocatalytic degradation of water pollutants, and disinfection of water-borne pathogens. Chloramine-T trihydrate was used as an example of organic pollutants in water, and many multi-drug-resistant bacteria and pathogenic fungi were employed as common water-borne microorganisms. Following this, the photocatalytic abilities of the prepared nanocomposite and the different factors (nanocomposite dose, chloramine- $\mathrm{T}$ initial concentration, and reaction $\mathrm{pH}$ ) affecting their efficacy were studied. Our results showed that the photodegradation of chloramine-T followed second order kinetics. In addition, degradation mechanism suggested that holes had a significant role in the photodegradation via chloramine-T oxidation or forming free radicals. Moreover, the prepared nanocomposite showed more promising antimicrobial potential (high ZOI, low MIC) than bare C-dots, and our previouslyreported nanocomposite $\left(\mathrm{Co}_{\mathrm{x}} \mathrm{Ni}_{1-\mathrm{x}} \mathrm{Fe}_{2} \mathrm{O}_{4} ; \mathrm{x}=0.9 / \mathrm{SiO}_{2} / \mathrm{TiO}_{2}\right)$, suggesting a synergistic effect of $\mathrm{C}$-dots with the nanocomposite. Notably, the antimicrobial ability of the prepared nanocomposite was significantly-increased after UV-irradiation. Above all, the synthesized nanocomposite showed a high ability for pathogenic-cell destruction as revealed by its good antibiofilm capabilities, suggesting a use for our nanocomposite in fighting multidrug-resistant bacteria and fungi. Our work provides a revolutionary, nanomaterial-based and cost-effective solution for wastewater treatment to assist in solving global water shortage issues.

Received: 17 April 2020; Accepted: 10 June 2020

Published online: 13 July 2020

\section{References}

1. Kummu, M., Ward, P. J., de Moel, H. \& Varis, O. Is physical water scarcity a new phenomenon? Global assessment of water shortage over the last two millennia. Environ. Res. Lett. 5, 034006 (2010).

2. Oki, T. \& Kanae, S. Global hydrological cycles and world water resources. Science 313, 1068-1072 (2006).

3. Bruun, C. Water shortage and surplus in the ancient world. In Cura aquarum in Sicilia (ed. Jansen, C. M.) 215-224 (Peeters Publishers, Leuven, 2000).

4. Schwarzenbach, R. P., Egli, T., Hofstetter, T. B., Von Gunten, U. \& Wehrli, B. Global water pollution and human health. Annu. Rev. Environ. Resour. 35, 109-136 (2010).

5. Amin, M., Alazba, A. \& Manzoor, U. A review of removal of pollutants from water/wastewater using different types of nanomaterials. Adv. Mater. Sci. Eng. https://doi.org/10.1155/2014/825910 (2014).

6. Jeevanantham, S. et al. Removal of toxic pollutants from water environment by phytoremediation: a survey on application and future prospects. Environ. Technol. Innov. 13, 264-276 (2019).

7. Lu, F. \& Astruc, D. Nanocatalysts and other nanomaterials for water remediation from organic pollutants. Coord. Chem. Rev. 408, 213180 (2020).

8. Dachir, S. et al. Decontaminant against toxic agents. In Skin Decontamination: A Comprehensive Clinical Research Guide (eds Zhu, H. \& Maibach, I.) 101 (Springer, Berlin, 2019). 
9. Powell, M. \& Harris, J. Influence of oxygen on the toxicity of chloramine-T to Atlantic salmon smolts in freshwater and seawater. J. Aquat. Anim. Health 16, 83-92 (2004).

10. Olmstead, M. M. \& Power, P. P. Crystal and molecular structure of chloramine-T trihydrate. Absence of a sodium-nitrogen interaction in the oxidant. N-chloro-N-sodiotoluene-p-sulfonamide. Inorg. Chem. 25, 4057-4058 (1986).

11. Beljaars, P. R. \& Rondags, T. M. High pressure liquid chromatographic determination of chloramine-T in food. J. Assoc. Off. Anal. Chem. 62, 1087-1091 (1979).

12. Wang, J., Li, Z. \& Yang, Y. Vortex-assisted liquid-liquid microextraction for the determination of chloramine-T in cosmetics coupled with high-performance liquid chromatography. Anal. Lett. 49, 1795-1803 (2016).

13. Kujala, V., Reijula, K., Ruotsalainen, E. \& Heikkinen, K. Occupational asthma due to chloramine-T solution. Respir. Med. 89, 693-695 (1995).

14. Dijkman, J. H., Vooren, P. H. \& Kramps, J. A. Occupational asthma due to inhalation of chloramine-T. Int. Arch. Allergy Immunol. 64, 422-427 (1981).

15. Powell, M. D. \& Perry, S. F. Cardio-respiratory effects of chloramine-T exposure in rainbow trout. Exp. Biol. Online 4, 1-59 (1999).

16. Masten, S. Chloramine-T [127-65-1] and Metabolite p-Toluenesulfonamide [70-55-3]: Review of Toxicological Literature. Toxicological Literature, Feb (2002).

17. Etani, K. (Google Patents, 1989).

18. Kasprzyk-Hordern, B., Ziółek, M. \& Nawrocki, J. Catalytic ozonation and methods of enhancing molecular ozone reactions in water treatment. Appl. Catal. B 46, 639-669 (2003).

19. Adams, C., Wang, Y., Loftin, K. \& Meyer, M. Removal of antibiotics from surface and distilled water in conventional water treatment processes. J. Environ. Eng. 128, 253-260 (2002)

20. Abd Elkodous, M. et al. Fabrication of ultra-pure anisotropic zinc oxide nanoparticles via simple and cost-effective route: implications for UTI and EAC medications. Biol. Trace Elem. Res. 196, 297-317. https://doi.org/10.1007/s12011-019-01894-1 (2019).

21. Wong, C. W. et al. Response surface methodology optimization of mono-dispersed $\mathrm{MgO}$ nanoparticles fabricated by ultrasonicassisted sol-gel method for outstanding antimicrobial and antibiofilm activities. J. Clust. Sci. 31, 367-389. https://doi.org/10.1007/ s10876-019-01651-3 (2020).

22. Elkhenany, H. et al. Comparison of different uncoated and starch-coated superparamagnetic iron oxide nanoparticles: implications for stem cell tracking. Int. J. Biol. Macromol. 143, 763-774. https://doi.org/10.1016/j.ijbiomac.2019.10.031 (2020).

23. El-Batal, A. I. et al. Factorial design-optimized and gamma irradiation-assisted fabrication of selenium nanoparticles by chitosan and Pleurotus ostreatus fermented fenugreek for a vigorous in vitro effect against carcinoma cells. Int. J. Biol. Macromol. 156, 1584-1599. https://doi.org/10.1016/j.ijbiomac.2019.11.210 (2019).

24. Samuel, M. S., Jose, S., Selvarajan, E., Mathimani, T. \& Pugazhendhi, A. Biosynthesized silver nanoparticles using Bacillus amyloliquefaciens; application for cytotoxicity effect on A549 cell line and photocatalytic degradation of p-nitrophenol. J. Photochem. Photobiol. B 202, 111642. https://doi.org/10.1016/j.jphotobiol.2019.111642 (2020).

25. Samuel, M. S. et al. Synthesized $\beta$-cyclodextrin modified graphene oxide ( $\beta$-CD-GO) composite for adsorption of cadmium and their toxicity profile in cervical cancer (HeLa) cell lines. Process Biochem. 93, 28-35. https://doi.org/10.1016/j.procbio.2020.02.014 (2020).

26. Samuel, M. S. et al. Preparation of graphene oxide/chitosan/ferrite nanocomposite for Chromium(VI) removal from aqueous solution. Int. J. Biol. Macromol. 119, 540-547. https://doi.org/10.1016/j.ijbiomac.2018.07.052 (2018).

27. Samuel, M. S. et al. Ultrasonic-assisted synthesis of graphene oxide - fungal hyphae: an efficient and reclaimable adsorbent for chromium(VI) removal from aqueous solution. Ultrason. Sonochem. 48, 412-417. https://doi.org/10.1016/j.ultsonch.2018.06.012 (2018).

28. Samuel, M. S., Bhattacharya, J., Parthiban, C., Viswanathan, G. \& Pradeep Singh, N. D. Ultrasound-assisted synthesis of metal organic framework for the photocatalytic reduction of 4-nitrophenol under direct sunlight. Ultrason. Sonochem. 49, 215-221. https://doi.org/10.1016/j.ultsonch.2018.08.004 (2018).

29. Elkodous, M. A., Hassaan, A., Ghoneim, A. \& Abdeen, Z. C-dots dispersed macro-mesoporous $\mathrm{TiO}_{2}$ phtocatalyst for effective waste water treatment. Charact. Appl. Nanomater. 1 (2018).

30. Huang, F., Yan, A. \& Zhao, H. Influences of doping on photocatalytic properties of $\mathrm{TiO}_{2}$ photocatalyst. Semicond. Photocatal. https://doi.org/10.5772/63234 (2016).

31. Choudhury, B. \& Choudhury, A. Oxygen defect dependent variation of band gap, Urbach energy and luminescence property of anatase, anatase-rutile mixed phase and of rutile phases of $\mathrm{TiO}_{2}$ nanoparticles. Physica E 56, 364-371 (2014).

32. Bosc, F., Edwards, D., Keller, N., Keller, V. \& Ayral, A. Mesoporous $\mathrm{TiO}_{2}$-based photocatalysts for UV and visible light gas-phase toluene degradation. Thin Solid Films 495, 272-279 (2006).

33. Ozawa, K. et al. Electron-hole recombination time at $\mathrm{TiO}_{2}$ single-crystal surfaces: influence of surface band bending. J. Phys. Chem. Lett. 5, 1953-1957 (2014).

34. Katoh, R., Murai, M. \& Furube, A. Electron-hole recombination in the bulk of a rutile $\mathrm{TiO}_{2}$ single crystal studied by subnanosecond transient absorption spectroscopy. Chem. Phys. Lett. 461, 238-241 (2008).

35. Yaghoubi, H. et al. Toward a visible light-driven photocatalyst: the effect of midgap-states-induced energy gap of undoped $\mathrm{TiO}_{2}$ nanoparticles. Acs Catal. 5, 327-335 (2015).

36. Neville, E. M. et al. Carbon-doped $\mathrm{TiO}_{2}$ and carbon, tungsten-codoped $\mathrm{TiO}_{2}$ through sol-gel processes in the presence of melamine borate: reflections through photocatalysis. J. Phys. Chem. C 116, 16511-16521 (2012).

37. Han, C. et al. Innovative visible light-activated sulfur doped $\mathrm{TiO}_{2}$ films for water treatment. Appl. Catal. B 107, 77-87 (2011).

38. Parastar, S. et al. Application of Ag-doped $\mathrm{TiO}_{2}$ nanoparticle prepared by photodeposition method for nitrate photocatalytic removal from aqueous solutions. Desalin. Water Treat. 51, 7137-7144 (2013).

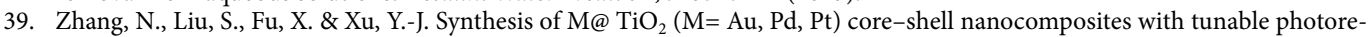
activity. J. Phys. Chem. C 115, 9136-9145 (2011).

40. Torimoto, T., Okawa, Y., Takeda, N. \& Yoneyama, H. Effect of activated carbon content in $\mathrm{TiO}_{2}$-loaded activated carbon on photodegradation behaviors of dichloromethane. J. Photochem. Photobiol. A 103, 153-157 (1997).

41. Tettey, K. E., Yee, M. Q. \& Lee, D. Photocatalytic and conductive $\mathrm{MWCNT} / \mathrm{TiO}_{2}$ nanocomposite thin films. ACS Appl. Mater. Interfaces. 2, 2646-2652 (2010).

42. Xiang, Q., Yu, J. \& Jaroniec, M. Graphene-based semiconductor photocatalysts. Chem. Soc. Rev. 41, 782-796 (2012).

43. Yu, H. et al. Smart utilization of carbon dots in semiconductor photocatalysis. Adv. Mater. 28, 9454-9477 (2016).

44. Chen, P. et al. Study on the photocatalytic mechanism and detoxicity of gemfibrozil by a sunlight-driven $\mathrm{TiO}_{2} /$ carbon dots photocatalyst: The significant roles of reactive oxygen species. Appl. Catal. B 204, 250-259 (2017).

45. Zhang, Y., Xu, M., Li, H., Ge, H. \& Bian, Z. The enhanced photoreduction of $\mathrm{Cr}$ (VI) to $\mathrm{Cr}$ (III) using carbon dots coupled $\mathrm{TiO}_{2}$ mesocrystals. Appl. Catal. B 226, 213-219 (2018).

46. $\mathrm{Li}$, Y. et al. Carbon dots- $\mathrm{TiO}_{2}$ nanosheets composites for photoreduction of $\mathrm{Cr}$ (VI) under sunlight illumination: favorable role of carbon dots. Appl. Catal. B 224, 508-517 (2018). 
47. El-Sayyad, G. S. et al. Merits of photocatalytic and antimicrobial applications of gamma-irradiated $\mathrm{Co}_{\mathrm{x}} \mathrm{Ni}_{1-\mathrm{x}} \mathrm{Fe}_{2} \mathrm{O}_{4} / \mathrm{SiO}_{2} / \mathrm{TiO}_{2}$; $\mathrm{x}=09$ nanocomposite for pyridine removal and pathogenic bacteria/fungi disinfection: implication for wastewater treatment. RSC Adv. 10, 5241-5259. https://doi.org/10.1039/C9RA10505K (2020).

48. Elkodous, M. A. et al. Layer-by-layer preparation and characterization of recyclable nanocomposite $\left(\mathrm{Co}_{\mathrm{x}} \mathrm{Ni}_{1-\mathrm{x}} \mathrm{Fe}_{2} \mathrm{O}_{4} ; \mathrm{X}=0.9\right.$ / $\mathrm{SiO}_{2} / \mathrm{TiO}_{2}$ ). J. Mater. Sci. 30, 8312-8328. https://doi.org/10.1007/s10854-019-01149-8 (2019).

49. Jia, X., Li, J. \& Wang, E. One-pot green synthesis of optically pH-sensitive carbon dots with upconversion luminescence. Nanoscale 4, 5572-5575 (2012).

50. Boyanova, L. et al. Activity of Bulgarian propolis against 94 Helicobacter pylori strains in vitro by agar-well diffusion, agar dilution and disc diffusion methods. J. Med. Microbiol. 54, 481-483 (2005).

51. Rothenburger, S., Spangler, D., Bhende, S. \& Burkley, D. In vitro antimicrobial evaluation of Coated VICRYL ${ }^{*}$ Plus Antibacterial Suture (coated polyglactin 910 with triclosan) using zone of inhibition assays. Surg. Infect. 3, s79-s87 (2002).

52. El-Batal, A., Haroun, B. M., Farrag, A. A., Baraka, A. \& El-Sayyad, G. S. Synthesis of silver nanoparticles and incorporation with certain antibiotic using gamma irradiation. Br. J. Pharm. Res. 4, 1341 (2014).

53. El-Batal, A. I., Al-Hazmi, N. E., Mosallam, F. M. \& El-Sayyad, G. S. Biogenic synthesis of copper nanoparticles by natural polysaccharides and Pleurotus ostreatus fermented fenugreek using gamma rays with antioxidant and antimicrobial potential towards some wound pathogens. Microb. Pathog. 118, 159-169 (2018).

54. El-Batal, A. I., El-Sayyad, G. S., El-Ghamery, A. \& Gobara, M. Response surface methodology optimization of melanin production by Streptomyces cyaneus and synthesis of copper oxide nanoparticles using gamma radiation. J. Clust. Sci. 28, 1083-1112 (2017).

55. El-Sayyad, G. S., Mosallam, F. M. \& El-Batal, A. I. One-pot green synthesis of magnesium oxide nanoparticles using Penicillium chrysogenum melanin pigment and gamma rays with antimicrobial activity against multidrug-resistant microbes. Adv. Powder Technol. 29, 2616-2625. https://doi.org/10.1016/j.apt.2018.07.009 (2018).

56. El-Batal, A. I., El-Sayyad, G. S., Mosallam, F. M. \& Fathy, R. M. Penicillium chrysogenum-mediated mycogenic synthesis of copper oxide nanoparticles using gamma rays for in vitro antimicrobial activity against some plant pathogens. J. Clust. Sci. 31(1), 79-90. https://doi.org/10.1007/s10876-019-01619-3 (2019).

57. Baraka, A. et al. Synthesis of silver nanoparticles using natural pigments extracted from Alfalfa leaves and its use for antimicrobial activity. Chem. Pap. 71, 2271-2281. https://doi.org/10.1007/s11696-017-0221-9 (2017).

58. Christensen, G. D., Simpson, W. A., Bisno, A. L. \& Beachey, E. H. Adherence of slime-producing strains of Staphylococcus epidermidis to smooth surfaces. Infect. Immun. 37, 318-326 (1982).

59. Ansari, M. A., Khan, H. M., Khan, A. A., Cameotra, S. S. \& Pal, R. Antibiofilm efficacy of silver nanoparticles against biofilm of extended spectrum $\beta$-lactamase isolates of Escherichia coli and Klebsiella pneumoniae. Appl. Nanosc. 4, 859-868 (2014).

60. El-Sayyad, G. S., El-Bastawisy, H. S., Gobara, M. \& El-Batal, A. I. Gentamicin-assisted mycogenic selenium nanoparticles synthesized under gamma irradiation for robust reluctance of resistant urinary tract infection-causing pathogens. Biol. Trace Elem. Res. 195, 323-342. https://doi.org/10.1007/s12011-019-01842-z (2019).

61. Abidi, S. H., Sherwani, S. K., Siddiqui, T. R., Bashir, A. \& Kazmi, S. U. Drug resistance profile and biofilm forming potential of Pseudomonas aeruginosa isolated from contact lenses in Karachi-Pakistan. BMC Ophthalmol. 13, 57 (2013).

62. Mathur, T. et al. Detection of biofilm formation among the clinical isolates of staphylococci: an evaluation of three different screening methods. Indian J. Med. Microbiol. 24, 25 (2006).

63. El-Nemr, K. F., Mohamed, H. R., Ali, M. A., Fathy, R. M. \& Dhmees, A. S. Polyvinyl alcohol/gelatin irradiated blends filled by lignin as green filler for antimicrobial packaging materials. Int. J. Environ. Anal. Chem. https://doi.org/10.1080/03067 319.2019.1657108 (2019).

64. Brownlee, K. (JSTOR, 1952).

65. Mewada, A. et al. Green synthesis of biocompatible carbon dots using aqueous extract of Trapa bispinosa peel. Mater. Sci. Eng. C 33, 2914-2917 (2013)

66. Maier, J. P. Electronic spectroscopy of carbon chains. J. Phys. Chem. A 102, 3462-3469 (1998).

67. Zhang, J. et al. Reduction of graphene oxide via L-ascorbic acid. Chem. Commun. 46, 1112-1114 (2010).

68. Luo, D., Zhang, G., Liu, J. \& Sun, X. Evaluation criteria for reduced graphene oxide. J. Phys. Chem. C 115, 11327-11335 (2011).

69. Schneider, P. Adsorption isotherms of microporous-mesoporous solids revisited. Appl. Catal. A 129, 157-165 (1995).

70. Terzyk, A. P., Gauden, P. A., Rychlicki, G. \& Wojsz, R. Fractal dimension of microporous carbon on the basis of Polanyi-Dubinin theory of adsorption. Part IV. The comparative analysis of two alternative solutions of the overall adsorption isotherm equation for microporous fractal solids. Colloids Surf. A 152, 293-313 (1999).

71. Abidin, S. Z., Mohamad, I., Hashim, A. B. \& Abdullah, N. Characterization of nanocarbon particles using nitrogen adsorption analysis: isotherm, pore type, pore size and BET surface area. Proc. Mech. Eng. Res. Day 2016, 127-128 (2016).

72. Sotomayor, F. J., Cychosz, K. A. \& Thommes, M. Characterization of micro/mesoporous materials by physisorption: concepts and case studies. Acc. Mater. Surf. Res. 3, 34-50 (2018).

73. Keerthana, B. G. T., Solaiyammal, T., Muniyappan, S. \& Murugakoothan, P. Hydrothermal synthesis and characterization of $\mathrm{TiO}_{2}$ nanostructures prepared using different solvents. Mater. Lett. 220, 20-23 (2018).

74. Chang, Q., Zhu, L., Yu, C. \& Tang, H. Synthesis and properties of magnetic and luminescent $\mathrm{Fe}_{3} \mathrm{O}_{4} / \mathrm{SiO}_{2} / \mathrm{Dye} / \mathrm{SiO}_{2}$ nanoparticles. J. Lumin. 128, 1890-1895 (2008).

75. Donia, A. M., Atia, A. A., Al-amrani, W. A. \& El-Nahas, A. M. Effect of structural properties of acid dyes on their adsorption behaviour from aqueous solutions by amine modified silica. J. Hazard. Mater. 161, 1544-1550 (2009).

76. Arévalo-Cid, P., Isasi, J. \& Martín-Hernández, F. Comparative study of core-shell nanostructures based on amino-functionalized $\mathrm{Fe}_{3} \mathrm{O}_{4} @ \mathrm{SiO}_{2}$ and $\mathrm{CoFe}_{2} \mathrm{O}_{4} @ \mathrm{SiO}_{2}$ nanocomposites. J. Alloy. Compd. 766, 609-618 (2018).

77. Ditta, A., Khan, M. A., Junaid, M., Khalil, R. A. \& Warsi, M. F. Structural, magnetic and spectral properties of Gd and Dy codoped dielectrically modified Co- $\mathrm{Ni}\left(\mathrm{Ni}_{0.4} \mathrm{Co}_{0.6} \mathrm{Fe}_{2} \mathrm{O}_{4}\right)$ ferrites. Phys. B 507, 27-34 (2017).

78. Amer, M. et al. Characterization and structural and magnetic studies of as-synthesized $\mathrm{Fe}_{2+} \mathrm{Cr}_{\mathrm{x}} \mathrm{Fe}_{(2-\mathrm{x})} \mathrm{O}_{4}$ nanoparticles. J. Magn. Magn. Mater. 439, 373-383 (2017).

79. Amer, M., Meaz, T., Mostafa, A. \& El-Ghazally, H. Structural and physical properties of the nano-crystalline Al-substituted Cr-Cu ferrite. J. Magn. Magn. Mater. 343, 286-292 (2013).

80. Kadam, R., Alone, S. T., Mane, M. L., Biradar, A. \& Shirsath, S. E. Phase evaluation of $\mathrm{Li}^{+}$substituted $\mathrm{CoFe}_{2} \mathrm{O}_{4}$ nanoparticles, their characterizations and magnetic properties. J. Magn. Magn. Mater. 355, 70-75 (2014).

81. Ghasemi, A. Compositional dependence of magnetization reversal mechanism, magnetic interaction and Curie temperature of $\mathrm{Co}_{1-\mathrm{x}} \mathrm{Sr}_{\mathrm{x}} \mathrm{Fe}_{2} \mathrm{O}_{4}$ spinel thin film. J. Alloy. Compd. 645, 467-477 (2015).

82. Zhu, C., Zhai, J. \& Dong, S. Bifunctional fluorescent carbon nanodots: green synthesis via soy milk and application as metal-free electrocatalysts for oxygen reduction. Chem. Commun. 48, 9367-9369 (2012).

83. Roy, P., Chen, P.-C., Periasamy, A. P., Chen, Y.-N. \& Chang, H.-T. Photoluminescent carbon nanodots: synthesis, physicochemical properties and analytical applications. Mater. Today 18, 447-458 (2015).

84. Zhou, W. et al. Towards efficient dual-emissive carbon dots through sulfur and nitrogen co-doped. J. Mater. Chem. C 5, 8014-8021 (2017).

85. Juang, R.-S. et al. Synthesis of carbon dots on $\mathrm{Fe}_{3} \mathrm{O}_{4}$ nanoparticles as recyclable visible-light photocatalysts. IEEE Trans. Magn. 53, $1-4(2017)$ 
86. Kurdekar, A. et al. Comparative performance evaluation of carbon dot-based paper immunoassay on Whatman filter paper and nitrocellulose paper in the detection of HIV infection. Microfluid. Nanofluid. 20, 99 (2016).

87. Gonsalves, L., Mojumdar, S. \& Verenkar, V. Synthesis of cobalt nickel ferrite nanoparticles via autocatalytic decomposition of the precursor. J. Therm. Anal. Calorim. 100, 789-792 (2010).

88. Tan, M. et al. Enhanced photoluminescence and characterization of multicolor carbon dots using plant soot as a carbon source. Talanta 115, 950-956 (2013).

89. Cheng, S. et al. Electrostatically assembled carbon dots/boron nitride nanosheet hybrid nanostructures for thermal quenchingresistant white phosphors. Nanoscale 12, 524-529 (2020).

90. Mahmoodi, N. M. Photocatalytic ozonation of dyes using copper ferrite nanoparticle prepared by co-precipitation method. Desalination 279, 332-337 (2011).

91. Albroomi, H., Elsayed, M., Baraka, A. \& Abdelmaged, M. Factors affecting the removal of a basic and an azo dye from artificial solutions by adsorption using activated carbon. J. Turk. Chem. Soc. A 2, 17-33 (2015).

92. Elsayed, M., Gobara, M. \& Elbasuney, S. Instant synthesis of bespoke nanoscopic photocatalysts with enhanced surface area and photocatalytic activity for wastewater treatment. J. Photochem. Photobiol. A 344, 121-133 (2017).

93. Mahmoodi, N. M. Zinc ferrite nanoparticle as a magnetic catalyst: synthesis and dye degradation. Mater. Res. Bull. 48, 4255-4260 (2013).

94. Elsayed, M. Application of ultraviolet and ultrasound irradiation for the degradation of pyridine in wastewater: a comparative study. Orbital 6, 195-204 (2014).

95. Casbeer, E., Sharma, V. K. \& Li, X.-Z. Synthesis and photocatalytic activity of ferrites under visible light: a review. Sep. Purif. Technol. 87, 1-14 (2012).

96. Elsayed, M. \& Gobara, M. Enhancement removal of tartrazine dye using $\mathrm{HCl}$-doped polyaniline and $\mathrm{TiO}_{2}$-decorated PANI particles. Mater. Res. Express 3, 085301 (2016).

97. Tang, Z.-X. \& Lv, B.-F. MgO nanoparticles as antibacterial agent: preparation and activity. Braz. J. Chem. Eng. 31, 591-601 (2014).

98. Wang, W., Yu, J., Xiang, Q. \& Cheng, B. Enhanced photocatalytic activity of hierarchical macro/mesoporous $\mathrm{TiO}_{2}$-graphene composites for photodegradation of acetone in air. Appl. Catal. B 119-120, 109-116. https://doi.org/10.1016/j.apcatb.2012.02.035 (2012).

99. Zhang, G. et al. Study on the photocatalytic and antibacterial properties of $\mathrm{TiO}_{2}$ nanoparticles-coated cotton fabrics. Materials 12, 2010 (2019).

100. Haghi, M. et al. Antibacterial effect of $\mathrm{TiO}_{2}$ nanoparticles on pathogenic strain of E. coli. Int. J. Adv. Biotechnol. Res. 3, 621-624 (2012).

101. Abdel-Rahman, H. A., Awad, E. H. \& Fathy, R. M. Effect of modified nano zinc oxide on physico-chemical and antimicrobial properties of gamma-irradiated sawdust/epoxy composites. J. Compos. Mater. 54, 331-343 (2019).

102. Maksoud, M. A. et al. Antibacterial, antibiofilm, and photocatalytic activities of metals-substituted spinel cobalt ferrite nanoparticles. Microb. Pathog. 127, 144-158 (2019).

103. El-Batal, A. I., Balabel, N. M., Attia, M. S. \& El-Sayyad, G. S. Antibacterial and antibiofilm potential of mono-dispersed stable copper oxide nanoparticles-streptomycin nano-drug: implications for some potato plant bacterial pathogen treatment. J. Clust. Sci. https://doi.org/10.1007/s10876-019-01707-4 (2019).

104. Ashajyothi, C., Harish, K. H., Dubey, N. \& Chandrakanth, R. K. Antibiofilm activity of biogenic copper and zinc oxide nanoparticles-antimicrobials collegiate against multiple drug resistant bacteria: a nanoscale approach. J. Nanostruct. Chem. 6, 329-341 (2016).

105. Park, H.-J. et al. Removal characteristics of engineered nanoparticles by activated sludge. Chemosphere 92, 524-528 (2013).

106. Priyadarshini, S. et al. Biosynthesis of $\mathrm{TiO}_{2}$ nanoparticles and their superior antibacterial effect against human nosocomial bacterial pathogens. Res. Chem. Intermed. 46, 1077-1089 (2019).

107. El-Batal, A. I., Mosalam, F. M., Ghorab, M., Hanora, A. \& Elbarbary, A. M. Antimicrobial, antioxidant and anticancer activities of zinc nanoparticles prepared by natural polysaccharides and gamma radiation. Int. J. Biol. Macromol. 107, 2298-2311 (2018).

108. El-Batal, A., El-Baz, A., AboMosalam, F. \& Tayel, A. Gamma irradiation induces silver nanoparticles synthesis by Monascus purpureus. J. Chem. Pharm. Res. 5, 1-15 (2013).

109. Stoimenov, P. K., Klinger, R. L., Marchin, G. L. \& Klabunde, K. J. Metal oxide nanoparticles as bactericidal agents. Langmuir 18, 6679-6686 (2002).

110. El-Batal, A. I., Mosallam, F. M. \& El-Sayyad, G. S. Synthesis of metallic silver nanoparticles by fluconazole drug and gamma rays to inhibit the growth of multidrug-resistant microbes. J. Clust. Sci. 29, 1003-1015 (2018).

111. Khan, M. F. et al. Sol-gel synthesis of thorn-like $\mathrm{ZnO}$ nanoparticles endorsing mechanical stirring effect and their antimicrobial activities: Potential role as nano-antibiotics. Sci. Rep. 6, 27689 (2016).

\section{Acknowledgements}

The authors would like to acknowledge the P.I. of Nanotechnology Research Unit (Prof. Dr Ahmed I. El-Batal), Drug Microbiology Laboratory, Drug Radiation Research Department, NCRRT, Egypt, for supporting this study under the project title "Nutraceuticals and Functional Foods Production by using Nano/Biotechnological and Irradiation Processes." The author, M. Abd Elkodous would like to express his deep gratitude to Nile University's Vice President for Research (Prof. Dr Ahmed Radwan) for his continued support. G. Kawamura would like to thank to JSPS KAKENHI (18K04701) and Tatematsu Foundation for their financial support.

\section{Author contributions}

M.A.E. executing experimental work, data analysis, paper writing, figure moderation and revision. G.S.E.: executing experimental work, data analysis, paper writing, figure moderation and revision. S.M.Y.: characterization of materials and figure moderation. H.G.N.: executing experimental work and data analysis. M.G.: characterization of materials. M.A.E.: data analysis and paper writing. A.M.E.: executing experimental work and data analysis. G.K.: characterization of materials, paper writing and figure moderation. T.W.K.: revision. A.I.E.: revision. A.M.: figure moderation, revision and supervision.

\section{Competing interests}

The authors declare no competing interest.

\section{Additional information}

Supplementary information is available for this paper at https://doi.org/10.1038/s41598-020-68173-1.

Correspondence and requests for materials should be addressed to G.K. or A.M. 
Reprints and permissions information is available at www.nature.com/reprints.

Publisher's note Springer Nature remains neutral with regard to jurisdictional claims in published maps and institutional affiliations.

(c) (i) Open Access This article is licensed under a Creative Commons Attribution 4.0 International License, which permits use, sharing, adaptation, distribution and reproduction in any medium or format, as long as you give appropriate credit to the original author(s) and the source, provide a link to the Creative Commons license, and indicate if changes were made. The images or other third party material in this article are included in the article's Creative Commons license, unless indicated otherwise in a credit line to the material. If material is not included in the article's Creative Commons license and your intended use is not permitted by statutory regulation or exceeds the permitted use, you will need to obtain permission directly from the copyright holder. To view a copy of this license, visit http://creativecommons.org/licenses/by/4.0/.

(C) The Author(s) 2020 